\title{
DESCRIPTIVE CATALOGUE OF THE COLLECTION OF BUDDHIST ART IN THE UNITED STATES NATIONAL MUSEUM.
}

\section{By I. M. Casanowicz,}

Assistant Curator, Division of Old World Archeology, United States National Museum.

\section{INTRODUCTION.}

The collection described in this catalogue includes material from Further India and the Far East. That from the former region consists chiefly in a collection of about 200 specimens coming from the Laos, a division of the widespread Thai or Shan race and ethnographically related to the Siamese, in Indo-China. The contributions from the Far East are divided between China, Japan, and Tibet. The greater part of the specimens from the last-named country has been described by the late William Woodville Rockhill in Notes On The Ethnology of Tibet. ${ }^{1}$ They are included in the present catalogue for the sake of completeness.

A special collection of objects of Buddhism from Burma, a deposit of Mr. S. S. Howland, was described under the title of The S. S. Howland Collection Of Buddhist Religious Art in the National Museum, by I. M. Casanowicz. ${ }^{2}$

INTRODUCTION.

THE FOUNDER OF BUDDHISM.

Buddhism arose at the end of the sixth or beginning of the fifth century B. C. as a schism or reformation of Brahmanism in India. Its founder, known by the names of Gautama, Sakyamuni, and Buddha, was Siddhartha, son of Suddhodanna of the family Gautama, rajah, of chieftain, of the Sakya clan, who were settled in the Ganges Valley, along the southern border of Nepal and the northeast part of Oude (Oudh), about a hundred miles north-northeast of Benares, with Kapilavastu as capital. Gautama, then, is the family name which the Sakyas assumed after one of the Vedic seers (Rishis), Sakya-Muni, means sage of the Sakyas, while Buddha is not a proper or personal name, but a title.

Later tradition has woven around the person and career of the founder a mass of myths and legends. So, for instance, that before

1 Report of the U. S. National Museum for 1893, pp. 730, etc.

2 Report of the U. S. National Museum for 1904, pp. 735-744, with 17 plates. 
his last life on earth he had gone through hundreds of rebirths in all forms of existence; or that for ages he had lived in Tushita, the heaven of the happy gods, and in the fullness of time was born in a supernatural way, having entered the body of his mother Maya in the guise of a white six-tusked elephant; that he was prompted to renounce the world and his career of a prince through the sight of sickness, old age, and death; that he was tempted by the fiend Mara who tried to divert him from his mission of a savior, and other similar myths. The simple facts of his career, so far as they can be freed from the later legendary accretions, may be said to be about as follows: Siddhartha, who was of a reflective and contemplative turn of mind and deeply impressed with the vanity and misery of life, retired from the world at the age of 29, after 10 years of married life and the birth of a son. This is called the "great renunciation." For six years he led the life of a wandering ascetic sage (muni), devoting himself to the study of the various systems of philosophy and theology of the times, and to severe ascetic practices, without finding in either a solution of the riddle of existence. In his thirty-fifth year he passed through a second mental crisis. While sitting in meditation under the famous Bo-tree (a species of Ficus religiosa, pipala) at Bodhi Gaya, south of the present Patna, he attained to the state of a Buddha - that is, of an "enlightened one," or "awakened one"having found the cause of the evils of existence and the way of deliverance from them.

For 45 years Buddha went about from place to place in the valley of the Ganges, proclaiming his good tidings and gathering around him a small band of faithful followers, the earliest members of his afterwards famous order, and finally died at the age of 80 , in the midst of his disciples, at Kusinagara, the modern Kasia, in the district of Gorakhpur, his body being cremated, and the relics distributed among the clans of the adjoining districts.

BUDDHA'S DOCTRINES (THE DHARMA).

The substance of the teaching of Buddha is expressed in the "four excellent truths": (1) Existence is inseparable from sorrow. Birth is sorrow, age is sorrow, sickness is sorrow, death is sorrow, clinging to earthly things is sorrow. (2) The causes of sorrow are our passions and desires which result in now birth with its consequent old age, sickness, death, and other miseries. For the present life of the individual is not the first one. Innumerable births have preceded it in previous ages. The attachment to life and its pleasures produces a new being, and the moral character of the thoughts and actions of the former existences fixes the condition of the new being. This is called the law of cause and effect, or Karma. The term properly means "doing," or "action," and comprises the doctrine of the everlasting effect of an act. It is the aggregate result of all 
previous acts in unbroken succession from the beginning of existence, which in the Buddhist conception of man, constitutes his character, his real self, his ego, as it were. This alone endures when an individual existence has come to an end, and if the thirst of living and the fire of passions are not entirely extinguished, it gathers around itself, as a kind of transmigration of character, new elements and results in a new sentient being, whose nature, condition, and fortune it determines. Individuals are merely the present and temporary links in a long chain of cause and effect. Each link is the summarized result of the various activities of all that have gone before, and is, in its turn, part and parcel of all that will follow. By the theory of Karma, Buddhism explains the mystery of fate in the apparent unequal distribution here of happiness and woe, entirely independent of moral qualities. What a man reaps, Buddhism teaches, that he must himself have sown, as whatsoever a man sows that shall he also reap. (3) The cessation of sorrow through the extinction of the passions, of evil desires and the attachment to material objects, which destroys the power of the senses so that they no longer give birth to new beings. (4) The way to cessation by following the eight-fold path: (1) Right views (that is, freedom from superstition or delusion), (2) right resolve (high and worthy of the intelligent earnest man), (3) right speech (kindly, open, truthful), (4) right conduct (peaceful, honest, pure), (5) right way of earning a livelihood (causing hurt to no living being), (6) right endeavor (in self-training and in self-control), (7) right mindfulness (the active and watchful mind), (8) right contemplation (earnest thought on the mysteries of life). Each of these terms is a summary of the manifold energies of thought, feeling, and will in various combinations and applications, and the whole may be characterized - to use a modern designation-as a system of "ethical culture." The general philosophical presuppositions of Gautama's system are: The inevitable connection of desire and suffering; the nonreality of any abiding ego-principle or self, and the impermanence of all individual existence. The ethical teachings of Buddha are founded on a definite method of self-culture and self-discipline which would lead to the extinction of the "three-fold fire" of self-deception, desire, and malevolence and to a release at once from suffering and becoming-Nirvana . The term nirvana, which literally means "going out" (like the flame of a candle), is used with three distinct significations: (1) Eternal blissful repose, the peace which puts an end to all striving (something like the "beatific vision" conceived by Christians); (2) extinction and absolute annihilation; (3) to Buddha it seemingly meant the dying down or going out of the fires of lust, hatred, anger, and delusion or dullness, the cardinal sins of Buddhism, and a consequent passionless calm beyond reach of temptation. By thus uprooting all desire, 
and by perfect detachment from life and its attractions, cessation of the renewal of existence will be attained. "Whence comes peace?" (Buddha is made to say) "When the fire of desire is extinguished, when the fire of hate is extinguished, when the fire of illusion is extinguished, when all sins and all sorrows are extinguished, then comes peace." So that one may "enter Nirvana" while still on earth. What might be the after-death state of such a released being Gautama refused to discuss. Buddhism thus proclaimed a mode of salvation in which every man may be his own savior, without reference to God or gods, to priest or ritual. It is the first universal religion addressing itself to all men and to every nation; the first religion which had the ambition to embrace all men, to gather the whole of mankind into a great unity. "Go into all lands and preach this gospel; tell them that the poor and lowly, the rich and high, are all one, and that all castes unite in this religion as unite the rivers in the sea."

THE BUDDHIST COMMUNITY (THE SANGHA).

The Buddhist community in the strict sense consists of an order of monks and nuns (Bhikshus and Bhikshunis) who, as a rule, live in monasteries and are vowed to celibacy, poverty, and obedience. The following ten commandments were given to members of the order: (1) Not to kill or even injure any sentient being, (2) not to steal, (3) not to commit adultery, (4) not to lie or use any manner of improper speech, (5) not to use intoxicating drinks, (6) not to take repasts at improper times (that is, after midday), (7) not to attend dances, plays, and public spectacles, (8) not to wear costly raiment and garlands, or use perfumes, (9) not to use high seats and beds, and (10) not to receive gold or silver. But already in Buddha's lifetime it was impracticable for all his adherents to retire from the world and join the order. On these lay-believers (Upasakas) only the first five of the ten injunctions are obligatory. Among the virtues recommended to the masses are reverence to parents and teachers, care for wife and children, submission to authority, control over self, patience, forbearance, humility and contentment, alms giving, respect for the life of sentient creatures, and care for the welfare of all living things.

Buddha, his doctrine, and the community form the triad (the "three jewels," triratna) of Buddhism, and the formula of confessing fellowship with Buddhism is: I take my refuge in the Buddha, in the Dharma, and in the Sangha.

\section{DIVISIONS OF BUDDHISM.}

Buddhism is divided into two great schools, which are themselves subdivided into many sects and subsects. The first, the Hinayana, or lesser vehicle (comparing the religion of Buddha to a vessel which carries men across the agitated and restless ocean of existence, samsara 
to the haven of Nirvana), which pretends to have preserved the original teachings of Buddha in greater purity and simplicity, prevails in Ceylon, Burma, and Siam, although even there Buddhism is overlaid and interwoven with animistic notions and practices; the second, the Mahayana, or "greater vehicle," which arose in the second or first century B. C. in India and spread northward to Nepal. Tibet, China, Mongolia, and Japan, adopted many popular elements of mysticism and magic and is permeated with metaphysical speculations. After the regions in which the Hinayana and Mahayana are dominant, they are also termed the southern and northern school, respectively. Some of the distinctive doctrines between the Hinayana school and that of the Mahayana are: (1) As regards the endeavor of the believer, the aim in the former is individual salvation by becoming an Arhat, or a perfected saint. Through contemplation on the four excellent truths and by following the eight-fold path he is freed from lust and desire and thus from undergoing rebirth; in the latter the believer strives to emulate Buddha to save others by becoming a Budhisattva, an aspirant to Buddahood. For according to the Buddhist doctrine, Gautama Sakyamuni, the historical founder of Buddhism, was only one of many Buddhas who appear in the world at intervals of many ages (Kalpas), when there is special cause for their presence, and they depart again when they have fulfilled the purpose for which they came, have set in motion the wheel of the law which they proclaim, and have founded an order destined to last for some period of time. With each there is a period in which the doctrine flourishes, then a gradual decline, when it is overthrown till a new teacher appears and once more establishes the lost truths. (2) In the Mahayana vehicle the founder was transformed from a man who could be born and die into a supermundane self-existent and everlasting being, surrounded by vast multitudes of Bodhisattvas, numerous as "the sands of Ganges," who occupy various heavens as their habitations. This is developed in the doctrine of the AdiBuddha, that is, the first, or primary Buddha, the Buddha unoriginated, the principle and ultimate postulate of existence. By five acts of contemplation (dhyani) he produced the five Buddhas of contemplation (Dhyani-Buddhas), the celestial prototypes or counterparts of the five human Buddhas (Manushi Buddhas), of whom Gautama was the fourth, and the fifth, Matreya, the Buddha of love, is still to appear (at the end of the present age). By the twofold power of knowledge and contemplation they give birth to Bodhisattvas of contemplation (Dhyani-Bodhisattvas). These celestial Bodhisattvas are charged with the providence of the world and with carrying on the work of an earthly (Manushi) Buddha after his demise until the arrival of a successor. The most known and most worshiped Dhyani-Buddha is Amitabha - endless light-the celestial counter- 
part of Sakya Muni, and president of the Sukhavati heaven, the Paradise of the West, and therefore plays a great part in the belief and ritual of Tibet, China, and Japan as funeral divinity. His Dhyani-Bodhisattva is Avalokitesvara or Padmapani, ruler of the present period and protector and patron of Tibet. In China and Japan he was transformed into, or identified with, Kuan-yin and Kuanon, respectively, the goddess of compassion and mercy. ${ }^{3}$

\begin{tabular}{|c|c|c|c|}
\hline & Human Buddhas. & Dhyani Buddhas. & Dhyani Bodhisattvas. \\
\hline $\begin{array}{l}3 \\
4 \\
5\end{array}$ & 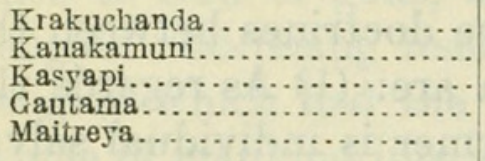 & 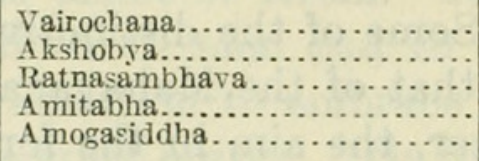 & $\begin{array}{l}\text { Sammantabhadra. } \\
\text { Vajrapani. } \\
\text { Ratnapani. } \\
\text { A valokitesvara or Padmapani. } \\
\text { Visvapani. }\end{array}$ \\
\hline
\end{tabular}

The opinion of the Mahayana adherents that every leader in their religious circles, every teacher distinguished for sanctity of life, was a Bodhisattva, besides introducing a crowd of deities from Hinduism and a multitude of attendant spirits and demons, opened the door to a flood of superstitious fancies, to a whole pantheon of gods, angels, saints, which appealed more strongly to the half-civilized races among which the Mahayana doctrine was propagated.

HISTORY OF THE SPREAD OF BUDDHISM.

Already at the death of Buddha the number of Buddhists seems to have been considerable. About the middle of the third century B. C., King Asoka, also called Piyadasi, grandson of Chandragupta, the Sandrokottos of the Greek historians, adopted Buddhism, and from the third century B. C. to the fourth century A. D. it was the dominant religion of India. But then its decline set in, and towards the end of the eleventh century A. D. it was entirely suppressed in India itself, the land of its origin. But meanwhile it spread, through the zeal of its missionaries, south and north. It was adopted by the kings of Ceylon in the third century B. C., a son of Asoka being the first missionary, and it is here that Buddhism is found almost in its pristine purity. From thence it was carried in the fifth century A. D. to Burma and in the seventh to Siam. Buddhism entered China in the first century A. D., but not until the fourth century did it obtain there any strong footing. It is found there in two sects-Foism, which was introduced from India; and Lamaism, which came from Tibet - side by side with Taoism and Confucianism. The preponderant rôle in Chinese Buddhism belongs to the celestial (Dhyani) Buddha Amitabha (Chinese, Omitofoh), the inspirer (spiritus rector) of Sakyamuni; and the Bodhisattva, Avaltokitesvara,

\footnotetext{
- Following is a synopsis of the five human or Manushi Buddhas of the present period of the world's existence (Kalpa) and their corresponding mystic or celestial counterparts (Dhyani-Buddhas), and their mystic successors (Dhyani-Bodhisattvas):
} 
who is here transformed into the female goddess of pity, Kuan-yin; and Manjusri (Chinese, Uenchu), the incarnation of science. But there also figure many Hindu deities under Chinese names in the Buddhist pantheon of China, besides numerous indigenous spirits and demons.

The same characteristics can be predicated of the Buddhism of Japan, where it penetrated from Korea in the sixth century A. D. It adopted also there many elements of Shintoism, the native religion of Japan, into its system, transforming the principal deities (Kami) of the Shintos into manifestations of Buddha and Buddhist saints.

Buddhism is supposed to have first entered Tibet from Nepal in the fourth century A. D. But it was only in the seventh century under the patronage of King Srongtsan-Gambo that it took root in the country and became its established religion. It was already on its arrival in Tibet penetrated with many beliefs and rites of Hinduism and was still more corrupted by assimilating many elements of the native religion, called Bon, which probably was some kind of demonism and Shamanism. In the fifteenth century the monk T'song-khapa undertook a reform of the Buddhism of Tibet to free it from its superstitions and abuses; but his efforts seem to have had little success or duration. The Tibetan Buddhism is a mixture of Hindu polytheism and mysticism and native demonolatry and sorcery. The genuine Buddhist doctrines as taught by Gautama Buddha play a little part in it. It has worked out an elaborate ritual with tonsured priests, processions, masses, holy water, incense, rosaries, confession, exorcism, and so forth, and by means of its powerful hierarchy it contrived to gain also political supremacy of the country. It developed into a hierarchical monarchy under the suzerainty of China. At the head of this church-state stands the Dalai Lama as abbot of the monastery of Gedun Dubpa near Lhasa, the capital and holy city ("God's place") of Tibet. Next to him in dignity is the Panchen Lama, head of the monastery of Tashi Lhunpo, which is situated about 70 miles west of Lhasa, to the right of the river Brahmaputra. ${ }^{4}$ These dignitaries, the first of whom has always held the highest rank in the Tibetan hierarchy, are believed to be incarnations of the Dhyani-Bodhisattva Avalokitesvara (Cenresi), the special patron and protector of Tibet, and of the Dhyani-Buddha Amitabha (Odpadmed or Ts'e-pa-med), respectively. On the death of the temporary incarnation of the Bodhisattva, that is, of the Dalai Lama, the spirit of the latter passes over to a child, the identity of whom

\footnotetext{
4 The title dalai, meaning "vast," literally, "ocean," was given to the grand lama of Lhasa by the Mongol prince Gusri Khan of Koko-Nor, who in 1640 A. D. conquered Tibet and made a present of it to the grand lama. The Tibetans call the Lhasa grand lama Gyalwa Rinpoche, "the gem of majesty" or "victory." The Tashi Lhunpo grand lamas are entitled Panchen Rinpoche, "the precious great doctor," or "great gem of learning," or Gyalgon Rinpoche, "the precious lordly victor." See L. A. Waddell the Buddhism in Tibet, London, 1895, pp. 227 and 235.
} 
being decided by divination. But also the abbots of the greater monasteries (chutuktus) are looked upon as incarnations of Bodhisattvas. Besides these quasi deified mystical persons, there are in the Tibetan church other hierarchical ranks and degrees. "The word 'lama,' written bla-ma and meaning 'the superior one,' is that given by Chinese and foreigners generally to the members of the Buddhist monastic order in Tibet. In Tibet, however, this word is reserved for those monks who have not only taken the highest theological degrees, but who have also led a saintly life and become famed for their knowledge. The word $d r a b a$ is used by Tibetans as a generic term for all persons connected with the order, monks as well as lay brethren." ${ }^{5}$

Buddhism wherever it went was modified by the national characteristics and inherited beliefs of its converts, so that fundamental doctrines were often overshadowed, sometimes destroyed, and it developed into strangely inconsistent and even antagonistic beliefs and practices. In accommodating itself to the genius and the habits of widely diversed peoples it was obliged to submit to various far-reaching compromises. It took on the color of any local condition and absorbed the native cults. In its development and expansion it gathered up into itself, like a snowball, all that-it found in its way and changed even its essentials. But for all that, the impress of Gautama's lofty teachings has not been blotted out. They became a vehicle of a superior civilization, and their influence in the realms of art, philosophy and religion has been profound. In the field of art, in particular, it may be said that Buddhism was creator and originator. It gave the keynote to painting, sculpture, and architecture of the East for many centuries much like Christianity did for the art of the West.

THE COLLECTION.

For the purpose of the descriptive catalogue the collection may be divided into:

I. The Buddhist Pantheon: (1) Images of Buddha; (2) images of Bodhisattvas and other divine beings.

II. The Buddhist Scriptures (Dharma).

III. The Buddhist Congregation (Sangha): (1) Saints and priests and their appurtenances; (2) religious edifices and their paraphernalia.

IV. Miscellanous: Magic, divination, ete.

\footnotetext{
6 W. W. Rockhill, Notes on the Ethnology of Tibet, p. 730. The political authority of the Dalai Lama is confined to Tibet itself, but he is the acknowledged spiritual head of the Lamaist Buddhists throughout Mongolia and China, as also by the Buriats and Kalmuks in Russia.
} 


\section{THE BUDDHIST PANTHEON.}

1. IMAGES OF BUDDHA.

In the early period of Buddhism no image of Buddha appears. It seems that the Buddhist artists deliberately abstained from attempting to model or depict the human form of the divine founder of their religion. His presence was indicated by certain signs of his activity, or symbols which referred to the main events or crises of his life, as the footprints which he left behind him; the sacred tree beneath which he obtained enlightenment; the wheel, which was adopted by his disciples as the symbol of his doctrine. It was about the beginning of the Christian era - four or five centuries after Buddha's decease - that his effigy was brought into common use, and soon became the leading feature of Buddhist decoration. ${ }^{6}$

After the Buddha image was once created, it was considered a meritorious and salutary act to represent as many Buddha figures as possible. Rows of Buddha figures were employed in the decoration of temple façades; whole rocks were turned into terrace-reliefs adorned with Buddhas, and caves were filled with thousands of Buddha statues of all sizes, and millions of Buddhists carry an image of him about their persons.

The most general orthodox type of Buddha images, which is probably the result of a long course of experiment, ${ }^{7}$ is that of a Hindu Yogi ascetic, sitting cross-legged in meditation, clad in a mendicant's garb, without any ornaments. The face, usually of Aryan cast of features, and unbearded, wears a placid and benign expression of passionless repose and serene dignity. ${ }^{8}$ The head is bare and roughly tonsured, the ragged contour of his cropped hair being ascribed to his having on his great renunciation cut off his tresses with his sword. His short locks are represented by Indian artists in the shape of seashells, perhaps following the tradition that once snails came out to shelter Buddha's head from the rays of the sun. In China and Japan the short locks sometimes take the form of round beads or sharp spikes. Among the 32 superior marks of beauty (mahapurushalakshanas) and the 80 smaller marks (annuvyanjana-lakshanas) ascribed to Buddha, as the most perfect form of man, are a protuberance (ushnisha) on the crown or vertex of the head, being the " hump of perfect wisdom;" a bead or little ball (urna) between the

6 The same conditions appear in early Christian art. For three centuries there were no pictures of Christ, but only symbols, as the fish, the lamb, the dove The catacombs of St. Callistus contained the first picture of Christ, the date being $313 \mathrm{~A}$. D. Rabulas in 586 first depicted the crucifixion in a Syriac Gospel. Images come in vogue with the development of cult and ritual. The spirit of adoration necessitates a visual icon; purely abstract symbols can not long content an adoring worshiper

7 The type of Christ was long a fluctuating one until that of Byzantium became universal.

8 “ There is no image so famuliar in the East as his (Buddha's); he sits everywhere, in monastery, pagoda, and sacred place, cross-legged, meditative, impassive, resigned, the ideal of quenched desire, without any line of care or thought to disturb the ineffable calm or mar the sweetness of his unsmiling, yet gracious face." A. M. Fairbairn, Philosophy of the Christian religion, p. 270. 
eyebrows; long ear lobs, sometimes reaching to the shoulder; long arms, which in the East is a mark of noble birth (recall Longimanus, epithet of Artaxerxes I). The robe is usually thrown over the left shoulder, leaving the right bare, except when he is represented preaching or walking abroad in public. The throne upon which he sits or stands is formed of a lotus flower (padmasana), which is sometimes supported by lions, elephants, or other animals, as a sort of heraldic shield. Behind his head is often displayed a nimbus or halo, frequently in form of a fig leaf, in remembrance of the tree (Ficus religiosa) under which he attained to Buddahood.

A prominent part in Buddhist iconography is played by the position of the hands (mudra), illustrating different incidents or favorite scenes in Buddha's life. They are in the main:

1. The attitude of meditation (dhyana-mudra), which occurs only in seated images. The legs are firmly locked and the soles directed fully upwards, while the hands are placed in the lap, one over the other.

2. The witness or earth touching posture (bhumisparssa-mudra). It marks the moment when Gautama sitting upon the diamond throne (vajrasana, so-called on account of its stability and indestructibility) under the bodhi-tree, was assailed by Mara, the Satan of Buddhist theology, challenging him to prove his qualification for Buddhahood, Gautama laid his hand upon the earth, calling upon the earth goddess (Prithivi) to bear testimony to his pious acts in his previous existences. Instantly the Earth goddess appeared and addressed the saint, saying: I am your witness. This posture is therefore used to indicate the bodhi, or enlightenment which immediately followed the "temptation," as Mara's assault is commonly ealled. The Buddha is invariably seated with the right-hand pendant over the throne, pointing to the earth. It is the most common form of all seated statues, almost the only one in vogue with Southern Buddhism (Burma, Ceylon, and Siam).

3. The attitude of preaching, or "turning the wheel of the law" (dharmachakra-mudra). The two hands are held in front of the breast, the thumb and forefinger of the right hand being joined and touching the middle finger of the left hand, or the right index finger turning down the fingers of the left hand. This posture of the hands is likewise confined to sedent statues.

4. Granting protection (abhaya-mudra). The right hand is raised at the level of the right shoulder, with palm of hand turned outwards. The left hand usually clasps the end of the upper robe, which is turned round the left arm so as to form a sleeve. This mudra is found both in standing and seated images.

5. The gift-bestowing attitude (varada-mudra). The right arm is stretched out downwards with the open palm of the hand turned to the front. This posture is associated only with standing figures. 
The features of the Buddha images described in the preceding are in greater part also extended to those of most of the Bodhisattvas or mythical Buddhas. It is therefore not always possible to determine whether an image represents Buddha or a Bodhisattva. For on the one hand individual Bodhisattvas are often given the rank of Buddhas, though not yet attained by them, and depicted in the Buddha type. On the other hand, the young princely figures elegantly draped and decked with ornaments instead of the plain monk's robe, which are the characteristics of Bodhisattvas, may as well represent Sakyamuni as Bodhisattva, before his attaining Buddhahood.

1. Buddha.-Made of bronze. Seated in meditation. The hands resting in the lap are disposed in such a way that the thumbs of both hands touch one another. The meditative repose is emphasized by the nearly closed eyes and the dreamy look of the countenance. The protuberance of the head is nearly hemispherical. There is a bead (urna) both on the head above the forehead, and below between the eyebrows. The ears are long and pierced. Behind the head is a circular halo of wood. The robe covers both shoulders, but leaves the breast bare, waves from the left round the lower part of the body and falls in ample folds over the feet. On the back of the figure is engraved a Japanese inscription in 13 lines which has been rendered as follows:

This bronze image of "The Buddha of Five Wisdoms," was made by Saburobiyoye Katsutane, son of the great caster, Yoshitane Tsuji of the Fujiwara clan, whose title was Tajima no Kami, Anson, who lived at the Port of Yasuno in the Province of Seishiu (Ise).

He respectfully cast it for Shichirouyemon Tadanori Takamine, who lives in the town of Matsuzaka in the district of Jidaka, Seishiu (Ise), whose religious name and the religious name of his wife are given, and "Who desire the blessings of future life for (the souls of) their Fathers, Mothers, and of six unnamed relatives, and for themselves."

It was respectfully offered by them to the temple of Joshozan Soan in Yamada, Seishiu (Ise), on the 15th day 9th month of the 1st (rat) year of the Period of KeianOctober 30th, 1648, when it was reverently consecrated by Shonin (Rev'd) Kwanseikudatsu, of the Society of Benren (Distinguished pure Lotus), twenty-first Priest of the temple of Sanyenzan Zojo, in the district of Shiba, Yedo, Province of Bushiu (Musashi).

Height, $38^{\frac{3}{4}}$ inches. Cast in Ise, Japan, 1648 A. D. (Plate 44, Cat. No. 12965, U.S.N.M.) ${ }^{9}$

2. Buddha.-Made of teak wood, black lacquered and gilt. Standing on a lotus pedestal, the right hand raised to the bosom, the left hand clasping the upper garment, the pose of granting protection. The robe covers the left shoulder, leaving the right shoulder and

- A brief sketch of Japanese bronze work in connection with a description of this figure is found in the Report of the U. S. National Museum, 1888-1889, pp. 729-735, under the title "On a bronze Buddhs in the U. s. National Museum." I3y Charles de Kay. 
arm bare. Around the forehead is a sort of diadem studded with colored stones. The latter also decorate the upper seam of the robe and the girdle round the waist, which terminates in a sash reaching to the ankles.

The lotus (Netumbium speciosum) is the queen of Indian flowers, to which a special sanctity is attached in the eyes of Buddhists and Hindus alike, and both Hindu and Buddhist divinities are usually represented standing or seated upon a lotus pedestal. With the Buddhist in particular it is a favorite object owing to its resemblance, when full blown, to the wheel, the symbol of the Buddhist doctrine (dharma). See also below under No. 300 .

Height, 6 feet 3 inches. Burma. (Plate 45, Cat. No. 129902, U.S.N.M.)

3. Buddha.-Made of wood. Sitting in meditation. Body and robe are painted yellow, the locks of small cones are black, the lips and insides of the nostrils and of the piercings of the ears are red. The eyes wide open, the mouth with full lips wears a faint smile, the face is round and rather short. The mendicant's robe is thrown over the left shoulder and comes down in ringed folds over the left arm and the legs. In place of a halo, five-forked flames issue from the crown of the head. This is common to Buddha statues of Ceylon and Siam and vary in the number of the flames from three to five and seven. On the palm of the right hand are painted in red, blue, and green colors (not seen on the plate) an open and closed lotus and concl shells, while the sole of the right foot is adorned, in the same colors, with wheels, lotuses, and the figures of an elephant and lion. The general signification of the lotus in Buddhist symbolism has been touched upon in the preceding No. 2. The wheel with "a thousand spokes" under the soles of the feet is one of the marks (lakshanas) of a Buddha. The symbolism of the wheel in India meant universal dominion, the great circle of power and rule. The "thousand-rayed wheel" on the soles of the feet of a child when born indicated that he will either be a chakravarti, that is, a universal monarch, whose wheel chakra, that is, chariot, rolls unresisted over all the world, or a perfect Buddha. The wheel then marks Buddha as a spiritual chakravarii. Legend has it that Buddha as soon as he entered this world walked seven steps to each of the cardinal points, taking, as it were, spiritual possession of the universe. In the picturesque language of the ancient Buddhist writings "turning of the wheel-of-the-law" stands for preaching the doctrine destined to traverse the world like the chariot wheels of a conquering monarch, and the wheel (dharma-chakra) has been adopted as a symbol of Buddha's doctrine and is often represented on the throne of statues, sometimes between two deer, in memory of the first sermon delivered by him, after he attained enlightenment, in the Deer Park at Sarnath, near Benares, when he 
"set rolling the royal chariot wheel of a universal empire of truth and righteousness."

The elephant is the symbol of sovereignty and one of the "seven jewels" which the chakravarti possesses, while the lion was the emblem of the Sakya clan from which Buddha sprung. Buddha himself bears the epithet Sakyasimha, "the lion of the Sakya race." Height to the summit of the flames, 7 feet 2 inches; to the crown of the head, 6 feet 7 inches. Ceylon. (Plate 46, Cat. No. 154977, U.S.N.M.)

4. Buddha.-Wood, lacquered and gilt. Represented standing on an hourglass-shaped base of a double lotus. The arms hanging flat by the sides. From the protuberance of the head (ushnisha) proceed five rays of flames, over which rises a metal umbrella. The figure is marked by stiffness and anatomical awkwardness. Height, 27 inches. Laos, Further India. (Cat. No. 517560, U.S.N.M.)

5. Buddha.-Bronze, lacquered and gilt.. Represented in the gift bestowing attitude walking, the right foot advancing, the raised left foot resting on the toes. The lotus throne is set on a triple octagonal base. From the head rise the five flames. The base is rather rudely cast, while the figure shows better work. Height, 26 inches. Laos, Further India. (Cat. No. 217506, U.S.N.M.)

6. Buddha.-Alabaster, red lacquered and gilt. Rudely executed. The ushnisha is covered with a headdress resembling a stupa which is characteristic of many Siamese and Burmese figures. The right hand points to the earth - the witness pose. The throne is supported by three elephants. Height, $17 \frac{1}{2}$ inches. Laos, Further India. (Plate 47, Cat. No. 217613, U.S.N.M.)

7. Buddha.-Old bronze. Represented in the witness pose. Round the throne is a frieze in relief of thirteen elephant heads, the middle one facing front while the six on either side of him face one another. Height, 12 inches. Laos, Further India. (Cat. No. 217503, U.S.N.M.)

8. Buddha.-Old bronze, lacquered and gilt. Represented in the witness position on a triple base, with the five rays issuing from the ushnisha. Fine work, but the head is broken off. Height, 21 inches. Laos, Further India. (Cat. No. 217505, U.S.N.M.)

9. Buddha.-Wood, lacquered and gilt. Seated in meditation on a high throne of a triple lotus which is inlaid with pieces of colored glass. The base of the five-forked flame on the head is studded with colored stones. Height, $21 \frac{1}{2}$ inches. Laos, Further India. (Cat. No. 217567, U.S.N.M.)

10. Buddha.-Bronze. Standing in the gift-bestowing attitude. The head is slightly bent forward, with an intent gaze of the wide open eyes downward. Around the brow is a circle of colored stones. The right hand is broken off. Height, 20 inches. India. (Cat. No. 158323 , U.S.N.M.) 
11. Buddha.-Bronze. Standing with the hands crossed, right over the left, in front; a rare position. Height, 17 inches. Laos, Further India. (Cat. No. 217524, U.S.N.M.)

12. Buddha.-Bronze. Standing in the attitude of granting protection. The locks of the head are arranged in spirals. On the forehead between the eyebrows is the precious jewel (urna). The robe is fitted round the neck, covering both shoulders, and coming down in waved folds. The cast of the countenance as well as the arrangement of the drapery show influence of Greek art, which left an indelible impress on the religious art of Asia from Gandhara in northwest India to Japan. Height, 29 inches. Japan. (Plate 48, Cat. No. 95037, U.S.N.M.)

13. Buddha.-Bronze. Similar to the preceding No. 12 , only smaller in size. Height, 12 inches. Japan. (Cat. No. 158320, U.S.N.M.)

14. Buddha.-Wood, lacquered and gilt. Seated in witness position on lotus. Well-executed workmanship. Height, $15 \frac{1}{2}$ inches. Laos, Further India. (Cat. No. 217565, U.S.N.M.)

15. Buddha.-Bronze. Standing in the gift-bestowing attitude, on crown of the head five rays. Height, 15 inches. Laos, Further India. (Cat. No. 217523, U.S.N.M.)

16. Buddha.-Wood, lacquered and gilt. Advancing figure on a double base, with arms hanging flat on the sides. Height, 13 inches. Laos, Further India. (Cat. No. 217602, U.S.N.M.)

17, 18. Buddha.-Wood, lacquered and gilt. Seated in witness position. The bases are adorned with conventional floral designs in gold on a black lacquered ground. Height, $10 \frac{1}{2}$ and 10 inches. Laos, Further India. (Cat. Nos. 217583-217584, U.S.N.M.)

19. Buddha.-Wood, gilded. Represented standing on a lotus which rests on an hourglass-shaped base, the left hand holding up the robe, the right hanging down flat. The base is inlaid with small round pieces of colored glass. Height, $11 \frac{1}{4}$ inches. India. (Cat. No. 158325, U.S.N.M.)

20. Buddha.-Bronze. Standing in the gift-bestowing attitude. An excellent grade of bronze combined with superior workmanship. The right hand is missing. Height, $13 \frac{1}{4}$ inches. Laos, Further India. (Cat. No. 217521, U.S.N.M.)

21. Buddha.-Bronze, gilt. Standing in the attitude of granting protection, with the usual five rays on the head. Height, 13 inches Laos, Further India. (Cat. No. 217522, U.S.N.M.)

22. Buddha.-Old bronze. Seated in witness position. The throne is raised on three legs. Height, 11 inches. Laos, Further India. (Cat. No. 217508, U.S.N.M.)

23. Buddha.-Old bronze. Similar to the preceding No. 22. The base is adorned with lotus buds in open work. Height, 12 inches. Laos, Further India. (Cat. No:217528, U. S. N. M.) 
24. Buddha.-Old bronze. Similar to No. 22. Height, 11 inches. Laos, Further India. (Cat. No. 217502, U.S.N.M.)

25. Buddha.-Wood, lacquered and gilt. Standing with left hand on bosom, the right hanging down. Height, $14 \frac{3}{8}$ inches. Laos, Further India. (Cat. No. 217593, U.S.N.M.)

26. Buddha.-Wood, lacquered and gilt. Seated on a double base in witness position. On back of the base is an inscription in Pali. Height, $11 \frac{7}{8}$ inches. Laos, Further India. (Cat. No. 217605, U.S.N.M.)

27. Buddha.-Wood, gilt. Standing with his right hand resting on a begging bowl (patra), the left hand holding some indeterminate object. The legend relates that the first food offered to Buddha after the attainment of supreme knowledge was by two merchants and consisted of honey and wheat. But Buddha reflecting that he must have an almsbowl, the four kings of the four quarters of the world (lokapalas) brought each one of gold, which he refused; then they brought silver, emerald, and ruby dishes, which were also refused; lastly, each brought an earthenware bowl, and Buddha causing them to unite in one, lest there should be jealousy, accepted the one from all. This bowl is now said to be kept in a palace at the bottom of the sea, but on the advent of Maitreya, the next Buddha of the present world age, it will divide into the original four, each of which is to be guarded by one of the four regents, as it is the palladium of Buddhism. Height, $9 \frac{1}{2}$ inches. Laos, Further India. (Cat. No. 217606, U.S.N.M.)

28. Buddha.-Bronze. Similar to No. 22. Good workmanship. Height, $10 \frac{1}{2}$ inches. Laos, Further India. (Cat. No. 217509, U.S.N.M.)

29. Buddha.-Old bronze. Seated in witness position. With inscribed base. Height, $10 \frac{1}{2}$ inches. Laos, Further India. (Cat. No. 217510 , U.S.N.M.)

30. Buddha.-Bronze. Seated in the witness position. With seven rays issuing from the crown of the head. Height, 9 inches, Laos, Further India. (Cat. No. 217514, U.S.N.M.)

31. Buddha.-Bronze. Similar to preceding No. 30 . Height, $10 \frac{1}{2}$ inches. Laos, Further India. (Cat. No. 217525, U.S.N.M.)

32. Buddha.-Bronze, richly gilded and chased. Seated in witness position on an ornamental triple throne. The robe, which is thrown over the left shoulder, is adorned in chased work with lotuses and other designs and studded with colored stones. On the front of the throne is a sort of shield, or perhaps intended to represent a cover hanging down. Height, 7 inches. Laos, Further India. (Plate 49, fig. 1, Cat. No. 217536, U.S.N.M.)

33. Buddha or Bodhisattva.-Bronze, richly gilded and chased. Standing on a triple base. The hands are raised in the attitude of $27177-21-$ Proc.N.M.vol.59-20 
veneration. The dress is decorated in chased work. From the wrists are suspended some ornaments in open and filigree work. On the shoulders, close to the neck, are similar ornaments. The ushnisha is surmounted by a spire. Height, 9 inches. Siam. (Plate 49, fig. 2, Cat. No. 168501, U.S.N.M.) Collected by Gen. John A. Halderman.

34. Buddha or Bodhisattva.--Bronze, richly gilded and chased. Seated on a rock, western fashion; that is, both legs pendant (the "Maitreya pose"), with the hands resting in the lap. The dress is adorned as in No. 33. On the left of the seat a baby elephant is holding up a vessel with water for Buddha to drink, on the right a bear cub is presenting a honey comb. Fine specimen of bronze work. Height, $8 \frac{1}{4}$ inches. Laos, Further India. (Plate 49, fig. 3, Cat. No. 217535, U.S.N.M.)

35. Buddha.-Old bronze. Seated in meditation. Heavy and careless casting. Height, $10 \frac{1}{2}$ inches. Laos, Further India. CatNo. 217507, U.S.N.M.)

36. Buddha.-Wood, red lacquered and gilt. Standing on the lotus, with the arms hanging flat on the sides. Rude work. Height, $9 \frac{5}{8}$ inches. Laos, Further India. (Cat. No. 217579, U.N.S.M.)

37. Buddha.-Wood, lacquered and gilt. Similar to the preceding No. 36. On the base is an inscription. Height, $9 \frac{1}{2}$ inches. Laos, Further India. (Cat. No. 217581, U.S.N.M.)

38. Buddha.-Carved, of ivory and gilt. Standing with the posture of the arms the same as in No. 36. Height, 6 inches. Laos, Further India. (Cat. No. 217629, U.S.N.M.)

39. Buddha and the earth goddess.-In two parts. On the upper portion Buddha seated in meditation. The top of his head is covered with a head dress resembling a stupa. Beneath, on the base, is represented, in high relief, the goddess of the earth wringing her hair. In the contest of Mara with Buddha, when the latter invoked the earth goddess as witness for his merits (see p. 300), the goddess, squeezing her hair, caused a huge river to issue therefrom, which swept away Mara and his hordes. Wood, lacquered and gilt. Height, 9 inches. Laos, Further India. (Plate 50, fig. 1, Cat. No. 217559, U.S.N.M.)

40. Buddha and the nagas.-Bronze relief, representing Buddha seated in a shrine in the witness attitude. This is set in a lacquered and gilt wooden plaque which is framed by eight intertwined nagas. The nagas belong to the category of demigods in the syncretistic system of later Buddhism. They are serpents having the power to assume human form, fabled to reside under the Trikuta rocks supporting Mount Meru, the center of the universe in Buddhist cosmology, and also in rivers, lakes, etc., watching over treasures, causing rain and certain maladies, and becoming dangerous when in anger. They have been converted by Buddha and showed great 
veneration and zeal for him and his doctrine. Nagas are represented on sculptures as giving the infant Gautama his first bath, immediately after his birth. Muchilinda, the King of the Nagas, protected Buddha from the rain after his enlightenment. In Buddhist art they are represented either in their animal form, as on this shrine, or, more ususal, in human form with a serpent placed over the head, or rather springing from behind the neck, as an ornament. Sometimes both forms are combined, the upper part being human with the heads crowned with serpents' hoods, while the lower part of the body, from the hips downward, is purely animal. Height, 11 inches; width, $6 \frac{3}{8}$ inches. Laos, Further India. (Plate 50, fig. 2, Cat. No. 217595, U.S.N.M.)

41. Buddha with disciples.-Wood, lacquered and gilt. Buddha seated in meditation, as in No. 39. Around the base are, in high relief, eight disciples kneeling, with hands joined, in the attitude of adoration. Height, $6 \frac{1}{2}$ inches. Laos, Further India. (Plate 50, fig. 3, Cat. No. 217594, U.S.N.M.)

42. The earth goddess.-Octagonal plaque, red lacquered, representing, in high relief, the earth goddess wringing her hair. See above, under No. 39. Height, $10 \frac{1}{2}$ inches; width, $8 \frac{1}{2}$ inches. Laos, Further India. (Cat. No. 217564, U.S.N.M.)

43. Buddha and nagas.-Carved of hom, lacquered and gilt. Buddha, in the witness posture, is sheltered by three nagas in the shape of cobras rising above his head, their coils forming his throne. See above under No. 40. Height, $5 \frac{1}{4}$ inches. Laos, Further India. (Cat. No. 217630, U.S.N.M.)

44. Buddha and disciples.-Wood, lacquered and gilt. Buddha in the witness attitude, the throne set on an octagonal hourglass-shaped base. Upon the base are, crudely carved in the round, eight disciples kneeling with uplifted hands in adoration, surrounding the throne. Compare No. 41. Height, $8 \frac{3}{4}$ inches. Laos, Further India. (Cat. No. 217604, U.S.N.M.)

45. Buddha.-Wood, lacquered and gilt. Seated in the witness position. The head covering is in form of an open lotus, from which proceed seven rays. The figure with its base is socketed into a throne formed of a crouching demoniac figure wound with the coils of two serpents, the tails of which he holds in his mouth. Perhaps intended for the Garuda, the mythical bird of India, who, like the Nagas (serpents), has the faculty of assuming human form, but is their deadly enemy, killing and injuring them whenever he can. Height, 15 inches. Laos, Further India: (Plate 51, Cat. No. 217566, U.S.N.M.)

46. Buddha.-Wood, lacquered and gilt. Seated in the witness attitude, with inscription on front of the base. Height, $7 \frac{1}{4}$ inches. Laos, Further India. (Cat. No. 217570, U.S.N.M.) 
47. Buddha.-Bronze. Seated in the witness posture on lotus throne, which rests on a base. Height, 9 inches. Laos, Further India. (Cat. No. 217517, U.S.N.M.)

48. Buddha.-Wood, lacquered and gilt. Seated in witness position on a double lotus. The robe in form of a folded shawl covers his left shoulder. Height, $8 \frac{3}{8}$ inches. Laos, Further India. (Cat. No. 217561, U.S.N.M.)

49. Buddha.-Wood, lacquered and gilt. Standing. The head is surmounted by seven rays. Fine work, but both arms are broken off. Height, 8 inches. Laos, Further India. (Cat. No. 217580, U.S.N.M.)

50. Buddha.-Bronze. Seated in witness position. The robe is folded over the left shoulder, falling over the knees. Height, $5 \frac{1}{2}$ inches. India. (Cat. No. 158324, U.S.N.M.)

51. Buddha.-Bronze, gilt. Similar to No. 47. Height, 10 inches. Laos, Further India. (Cat. No. 217534, U.S.N.M.)

52. Buddha or Bodhisativa.-Bronze. Seated. The head is bent forward and is covered with a high-peaked crown. The arms are adorned with armlets and bracelets. The hands, with fingers bent, are held one over the other. Height, $6 \frac{1}{4}$ inches. Japan. (Plate 52, fig. 1, Cat. No. 220138, U.S.N.M.) Lent by Miss Eliza R. Scidmore

53. Buddha.-Bronze. Seated in meditation on an ebony chair carved with lotus in openwork. The protuberance (ushnisha) on the head is gathered to a knot or tuft and is surrounded with a sort of diadem in openwork. The robe is fitted around the neck, covering both shoulders, incasing the arms in wide sleeves and falling down in ample folds over the knees. Height, $9 \frac{1}{2}$ inches. China (Plate 52, fig. 2, Cat. No. 281273, U.S.N.M.) Gift of Mrs. Belle Bushnell.

54. Buddha.-Bronze chased. Seated on an ornamental throne, with something like a shield in front, similar to No. 32 . The right hand is holding a rice ball, while the left rests on the knees. It is the custom of the temple service in Laos to place a vessel of steamed rice and a vessel of water before the image of Buddha. Height, $5 \frac{1}{2}$ inches. Laos, Further India. (Plate 52, fig. 3, Cat. No. 217515, U.S.N.M.)

55. Buddha or Bodhisattva.--Bronze, originally gilded, but the gilding has largely disappeared. Seated in meditation. The form of the protuberance, the arrangement of the robe, and the mural crown or diadem are the same as in No. 53. This figure is, in addition, adorned with necklaces and pendants and holds in the hands a mace or scepter. Height, $7 \frac{1}{2}$ inches. China. (Cat. No. 236805, U.S.N.M.) Lent by August Wall.

56. Buddha.- Soft stone. Seated, with the hands resting squarely on the knees. The head is covered with a low, flat cap. The robe 
covers both shoulders and falls in folds over the knees. Height, $13 \frac{1}{2}$ inches. Torai, Korea. (Cat. No. 151600, U.S.N.M.)

57. Buddha.-Bronze. Seated in witness position. The throne is raised on three legs. Height, $6 \frac{3}{4}$ inches. Laos, Further India. (Cat. No. 217518, U.S.N.M.)

58-59. Buddha.-Wood lacquered and gilt. Seated in witness position on an hourglass-shaped base. Height, $7 \frac{3}{4}$ inches. Laos. Further India. (Cat. No. 217568-9, U.S.N.M.)

60. Buddha.-Wood, lacquered and gilt. Seated with hands folded in the robe in lacquered and gilt shrine. Height, $5 \frac{3}{4}$ inches. Japan. (Cat. No. 311798, U.S.N.M.) Bequest of Miss Elizabeth S. Stevens.

61. Buddha.-Wood, gilt. Standing in the gift-bestowing attitude. The left hand is broken off. Height, $4 \frac{3}{4}$ inches. Japan. (Cat. No. 154271 , U.S.N.M.)

62. Buddha.-Wood, lacquered and gilt. Standing in the giftbestowing attitude. Height, 6 inches. Kobe, Japan. (Cat. No. 154822, U.S.N.M.)

63. Buddha.-Wood, lacquered and gilt. Seated in the witness posture. Height, $5 \frac{1}{2}$ inches. Laos, Further India. (Cat. No. 217587, U.S.N.M.)

64. Buddha,-Bronze. Seated in witness position. Height, $7 \frac{1}{4}$ inches. Laos, Further India. (Cat. No. 217519, U.S.N.M.)

65. Buddha.-Bronze, gilt. From the top of the head issue three rays. The base on which the lotus throne rests is adorned with a frieze of openwork in which are set five figurines in pointed arches. Perhaps intended for the five Buddhas of the present world-age (Kalpa), of whom Gautama was the fourth, and the fifth is still to appear as Maitreya, the Buddha of love. Height, $6 \frac{1}{4}$ inches. Laos, Further India. (Cat. No. 217520, U.S.N.M.)

66. Buddha.-Wood, lacquered and gilt. Standing in the attitude of gift bestowing. Height, $4 \frac{3}{4}$ inches. Japan. (Cat. No. 127274, U.S.N.M.)

67. Buddha.-Marble. Seated in the witness position. The robe, in form of a folded shawl, is thrown over the left shoulder. Height, 6 inches. Burma. (Plate 53, fig. 1, Cat. No. 151432, U.S.N.M.)

68. Buddha.-Gray alabaster. Seated in the witness position. The head is surmounted by a stupa-like crown, with a sort of halo behind it, while the arms are adorned with armlets. Height, $7 \frac{1}{4}$ inches. Burma. (Plate 53, fig. 2, Cat. No. 129543, U.S.N.M.)

69. Buddha.-Gray alabaster. Seated in the witness position. Height, 8 inches. Burma. (Plate 53, fig. 3, Cat. No. 175192, U.S.N.M.) 
70. Buddha.-Gray alabaster. Seated in the witness position. Height, $4 \frac{3}{4}$ inches. Burma. (Cat. No. 311813, U.S.N.M.) Bequest of Miss Elizabeth S. Stevens.

71, 72. Buddha.-White limestone. Seated in the witness position. Height, $8 \frac{3}{4}$ inches each. Burma. (Cat. Nos. 175191, 175192 U.S.N.M.)

73. Buddha.-White alabaster, red lacquered and gilt. Seated in the witness position, the lotus resting on a high base which is inscribed on the back. The garment is folded on the left shoulder. On the head is the high-peaked crown and round the neck three bands. Height, $17 \frac{5}{8}$ inches. Laos, Further India. (Cat. No. 217612, U.S.N.M.)

74-84. Buddha.-White alabaster. Similar to No. 73. These alabaster figures are rather crudely carved. The eyes and mouth are indicated by mere lines, the dress is represented by a gilded band or sash on the left shoulder. But they are highly valued by the Loas Buddhists on account of their being white, which is believed to be due to a Deva (semidivine being) guarding the figures and keeping them white and pure. During a drought they are carried in procession to cause a rainfall. Height, 4 to $8 \frac{1}{4}$ inches. Laos, Further India. (Cat. Nos. 217614-217624, U.S.N.M.)

85. Buddha.-Wood, lacquered and gilt. Standing on a double lotus, which is surrounded by an hexagonal railing, resting on a richly carved and gilt triple base. There is a double urna (precious bead) over the forehead and between the eyebrows, as in No. 1. The robe covers both shoulders and comes down in graceful folds to the feet. The cast of the face and the arrangement of the drapery exhibit strong Greek influence. The halo, in form of a fig leaf, rises from the lotus base and terminates in a sharp point overarching the head. The arms, which probably were in the posture of affording protection are missing. Height, of the figure, 12 inches; of the base, 6 inches. Japan. (Cat. No. 154271, U.S.N.M.)

86. Buddha.-Wood, black lacquered and gilt. Seated in the witness position. Height, $5 \frac{1}{2}$ inches. Laos, Further India. (Cat. No. 217591, U.S.N.M.)

87. Buddha.-Bronze, gilt. Seated in the witness position. Height, $5 \frac{1}{4}$ inches. Laos, Further India. (Cat. No. 217608, U.S.N.M.)

88. Buddha or Bodhisattva.-Bronze, richly gilt with various adornments. Much oxidized. Height, 3 inches. Laos, Further India. (Cat. No. 217529, U.S.N.M.)

89. Buddha.-Wood, lacquered and gilt. Witness position, with the posture of the hands reversed; that is, the left hand is pointing to the earth, instead of the right. Rudely carved. Height, $3 \frac{1}{2}$ inches. Laos, Further India. (Cat. No 217586, U.S.N.M.) 
90. Buddha.-Old bronze relief. Buddha walking, stepping out with the left foot. The head is facing front, while the body is slightly turned to the left. The left arm is raised to the breast, while the right hangs flat on the side. Shows Greek influence. Height, $4 \frac{5}{8}$ inches. Loas, Further India. (Cat. No. 217530, U.S.N.M.)

91. Buddha.-Wood, lacquered and gilt. Seated in meditation. Rude carving, and there is no throne or base. Height, $2 \frac{1}{2}$ inches. Laos, Further India. (Cat. No. 217588, U.S.N.M.)

92. Buddha.-Made of a gummy substance, lacquered and gilt. Seated in meditation. Height, $3 \frac{3}{4}$ inches. Laos, Further India. (Cat. No. 217590, U.S.N.M.)

93. Buddha.-Wood, lacquered and gilt. Seated in witness position. Height, $2 \frac{5}{8}$ inches. Laos, Further India. (Cat. No. 217589, U.S.N.M.)

94. Buddha.-Bronze, lacquered and gilt. Seated in witness position. Height, $2 \frac{7}{8}$ inches. Laos, Further India. (Cat. No. 217531, U.S.N.M.)

95. Buddha.-Bronze, gilt. Seated in meditation. Crude work. Height, $3 \frac{1}{2}$ inches. Laos, Further India. (Cat. No. 217532, U.S.N.M.)

96. Buddha.-Bronze, lacquered and gilt. Seated in the witness position. Height, $2 \frac{1}{4}$ inches. Laos, Further India. (Cat. No. 217533, U.S.N.M.)

97. Buddha.- Seated in the witness position. The head is of silver; the body and base of a gummy substance which has been overlaid with a casing of silver foil, most of which has disappeared. The base is traced with a net pattern and checkers. Height, 6 inches. Laos, Further India. (Cat. No. 217609, U.S.N.M.)

98. Buddha.-Similar to the preceding No. 97. On the base are tracings of a net pattern and floral designs. Height, 5 inches. Laos, Further India. (Cat. No. 217610, U.S.N.M.)

99-104. Buddha.-Seated in the witness position. Made of a gummy substance, overlaid with silver foil. The bases are decorated with a tracing of geometrical designs. Height, 2 to $2 \frac{1}{2}$ inches. Laos, Further India. (Cat. Nos. 217553-217558, U.S.N.M.)

105. Buddha.-Brass. Seated in meditation in lacquered and gilt shrine. Height, $3 \frac{3}{4}$ inches. Japan. (Cat. No. 77125, U.S.N.M.)

106. Buddha.-Wood, lacquered and gilt. Seated in the witness position. Height, $4 \frac{1}{2}$ inches. Laos, Further India. (Cat. No. 217592, U.S.N.M.)

107, 108. Buddha.-Bronze relief, gilt. Seated in the witness position on a double lotus throne within an arch which rests on columns. Height, 4 inches; width, $1 \frac{7}{8}$ inches. Laos, Further India. (Cat. Nos. 217641 and 217643, U.S.N.M.)

109. Buddha.-Carved flat shrine or niche, black and red lacquered, set with beads of colored glass. In the recess of the niche is a bronze 
relief representing Buddha seated under a canopy in the witness posture. In the background is seen the sacred Bo tree under which Gautama attained to Buddhahood. Height, $8 \frac{1}{2}$ inches. Laos, Further India. (Cat. No. 217576, U.S.N.M.)

110. Buddha in a niche or shrine.-Similar to he preceding (No. 109), only that in this the attitude is of meditation. The head of the Buddha figure is broken off. Height, 8 inches. Laos, Further India. (Cat. No. 217577, U.S.N.M.)

111. Buddha.-Bronze relief, representing Buddha seated in the witness posture on a double throne with a halo in shape of a fig leaf. Height, $3 \frac{1}{2}$ inches; width, $1 \frac{1}{2}$ inches. Laos, Further India. (Cat. No. 217692 , U.S.N.M.)

112. Buddha.-Antique ivory carving, in form of a pointed cone, gilt and mounted. Obverse, two seated Buddhas, one above the other, the upper in meditation, the lower in the witness attitude; reverse, the sacred Bo tree. Height, $9 \frac{1}{2}$ inches. Laos, Further India. (Cat. No. 217627, U.S.N.M.)

113. Buddha.-Antique ivory carving, in form of a pointed cone, gilt and mounted. On both sides, Buddha in the witness position under the Bo tree. Height, $6 \frac{1}{2}$ inches. Laos, Further India. (Cat. No. 217628, U.S.N.M.)

114. Buddha.-Terra-cotta relief. Buddha, in the attitude of gift bestowing, standing on a lotus which rests on an elaborately carved base. The dress, which covers the whole body, is adorned with horizontal bands modeled of floral designs in relief. On the arms are bracelets. On either side of the figures are richly carved columns which closed on to an arch which has broken away. The relief is of ancient Cambodian workmanship and was apparently removed from the wall decorations of a temple. Height, $7 \frac{3}{4}$ inches; width, $3 \frac{1}{4}$ inches. Laos, Further India. (Cat. No. 217638, U.S.N.M.)

115. Buddha.-Terra-cotta relief (fragment), showing Buddha seated in meditation. Over his head is an umbrella, and on the sides lotus buds (?). Height, 5 inches; width, $3 \frac{1}{2}$ inches. Laos, Further India. (Cat. No. 217632, U.S.N.M.)

116-119. Buddha.-Old terra-cotta reliefs, representing Buddha in the witness position. Height, $2 \frac{1}{2}$ to $2 \frac{1}{4}$ inches. Laos, Further India. (Cat. Nos. 217634-217637, U.S.N.M.)

120. Buddha.-Clay plaque, rounded at the top, with a raised rim all around. Inside is a miniature figurine of Buddha in the center, surrounded by some 50 still smaller figurines of disciples. Height, $4 \frac{1}{2}$ inches; width, $3 \frac{3}{4}$ inches. India (?). (Cat. No. 276834, U. S.N.M.)

121. Plaster cast of the face of Buddha.-From an ancient statue in Korea. Height, $9 \frac{1}{4}$ inches. Korea. (Cat. No. 129594, U.S.N.M.)

122. Buddha.-Bust, made of a gummy substance, lacquered and gilt. Height, 5 inches. Laos, Further India. (Cat. No. 217611, U.S.N.M.) 
123. Bronze head of Buddha.-From a statue found in the ruins of the Wat-Pra-Shan-Tan temple, near Lakawu Lampang. The face shows a noble tranquil expression. From the crown of the head issue five rays. Traces of gilding are discernible. Height, 6 inches Laos, Further India. (Cat. No. 217511, U.S.N.M.)

124. Terra-cotta head of Buddha.-From a statue found in the ruins of Wat-Yaphra-Khaw, "the temple of the women of the white cloth." Fine work. Laos, Further India. (Cat. No. 217639, U.S.N.M.)

125. Buddha figurines in clam shell.- These images on a shell are made by the natives of China by taking a large kind of clam (Alasmodonta) and gently attaching leaden images of Buddha under the fish, after which it is thrown back into the water. Nacre is deposited over the lead, and after a few months the shells are retaken, cleaned, and sent abroad as proofs of the power and presence of Buddha. $6 \frac{1}{2}$ by $4 \frac{3}{4}$ inches. Ningpo, China. (Plate 54, Cat. No. 127111, U.S.N.M.)

126. Parinirvana.-Buddha dying, or, as the Buddhist ritual expresses it, entering nirvana. Alabaster. Length, 34 inches. India. (Plate 55, Cat. No. 158322, U.S.N.M.)

127. Parinirvana.-Buddha entering nirvana. Wooden canopy, red and gold lacquered. It consists of a square base around the edges of which are set uprights and at one end is a panel carved in open work, while the roof has extended eaves. On the platform is a figure of Buddha lying on the right side, the head resting on some low support, surrounded by eight disciples. Of these one holds a vase (with medicine, or the ambrosia of nirvana), another is weeping, and the hands of the rest are in the posture of adoration. One of the disciples is missing. Height, 21 inches; length, 13 inches; width, 9 inches. Laos, Further India. (Plate 56, Cat. No. 217668, U.S.N.M.)

128-131. Parinirvana.-Buddha entering nirvana. Antique bronzes, representing Buddha lying on his right side, his head resting on a round pillow. Height, 4 inches: length, 7 to $8 \frac{1}{2}$ inches. Laos, Further India. (Cat. Nos. 217512, 217516, 217526, 217527, U.S.N.M.)

132. Parinirvana.-Buddha entering nirvana. Terra-cotta relief, gilt. Length, $4 \frac{1}{4}$ inches. Laos, Further India. (Cat. No. 217633, U.S.N.M.)

133. Horns of Buddha.-Bronze, lacquered and gilt. According to the tradition preserved in the Jatakas, which form a part of the Buddhist sacred literature, Gautama had passed through 550 existences in all created forms-as God, as man, as animal-till in his last incarnation, as the son of Suddhodanna, he appeared as the savior of mankind. These horns are believed by the Laos to be the 
actual horns of Buddha from a former incarnation as a bull. They were found at a relic shrine (stupa) claimed to have been erected on the spot where this bull is said to have died. The shrine and the lake near by still bear the name of this bull and are regarded as a sacred spot. On the front of the horns is carved in archaic style Buddha in the witness position; on the back, standing with the arms hanging flat on the sides. Height, $7 \frac{3}{4}$ inches; length of the base, $8 \frac{3}{4}$ inches. Laos, Further India. (Plate 57, Cat. No. 217625, U.S.N.M.)

134. Buddha's footprint (Duddhapada).-Cast from the original at Buddhagaya, Magadha, India. Supposed footprints of Buddha are found in various Buddhist countries, to which devout Buddhists make pilgrimages and present offerings. Most celebrated are the footprints on the gateways of the tope of Sanchi, in Bhopal (central India), on which are marked beside the wheel 108 compartments, each occupied by some sacred object (as a trident, a flower, a candle, a book, angels, the planets, etc.). ${ }^{10}$ Length, $25 \frac{1}{2}$ inches. India. (Plate 58, Cat. No. 76219, U.S.N.M.)

2. IMAGES OF BODHISATTVAS AND OTHER DIVINE BEINGS.

135. Amitabha (?).-Wood, lacquered and gilt. Seated in the "easy pose" (lalita sana), the left leg hanging down with inclination slightly inwards, the right drawn up and loosely bent. The ushnisha is gathered to a knot or tuft. The forehead was adorned with a metal ornament resembling a diadem, which has fallen off. The dress is elaborate and ornate. The right hand holds a wand or scepter, the object which was in the left hand is missing. Behind the head is a circular halo and another one behind the body, both with a beaded border and set in a fig leaf-shaped aureole carved with scrolls in open work. The seat represents a rock round which is coiled a dragon, the emblematic mythical animal of China and Japan. Amitabha, or as the Japanese name him, Amida, is one of the five celestial meditation (dhyani) Buddhas, who rules over the Sukhavati heaven of the west. $\mathrm{He}$ is the celestial reflex or counterpart of Gautama Buddha. He is the "Buddha of infinite light," and is in the entire northern Buddhism the most popular divinity and his image the most widely spread. The identification of this figure as that of Amitabha is, however, tentative. Height of the figure, 25 inches; of the base, 19 inches; length of the base, 20 inches; width, 16 inches. Japan. (Plate 59, Cat. No. 154964, U.S.N.M.)

10 Most famous is the footprint on Adam's Peak in Ceylon, which Buddha is said to have left on the accasion of his mythical visit to Ceylon. The cavity of about 5 feet long on the summit of the peak has been claimed by the Buddhists for Buddha, by the Sivaites for Siva, by the Christians for St. Thomas, who, according to tradition, had carried Christianity to India, and by the Mohammedans for Adam, who alighted on it when he was expelled from Paradise. The name Adam's Peak was given to the mountain by the Portuguese, who called it Pico de Adam.-The Portuguese authorities were divided between the conflicting claims for the footprint of St. Thomas and the eunuch of Queen Candace, mentioned in Acts viii, 27. The footprint of Buddhagaya is now worshipped as that of Vishnu. 
136. Amitabha (?).-Wood, lacquered and gilt. Seated in meditation on a full-blown lotus throne which is supported by a lion couchant on a rock which rests on a plinth, in a wooden shrine. The head wears an elaborate crown, in a filigree work. On the ears are similarly worked ornaments from which a necklace or chain hangs down over the breast. Height of the figure, $12 \frac{1}{2}$ inches; of the shrine, 24 inches. Shei Sheiva, Japan. (Cat. No. 154293, U.S.N.M.)

137. Tse-pa-med (Sanskrit Amitayus).-Bronze, chased and gilt. Amitayus with the Tibetan Buddists is the active spiritual reflex of Amitabha and is worshipped as the Buddha of long life (while Amitabha is the Buddha of "boundless light"). The Chinese confuse him with Amitabha. He is represented seated on a double lotus, holding before him in his right hand a bowl (often a skull) filled with water of life, which is one of the eight luck-compelling symbols of ancient India, the left hand rests with upturned palm in his lap under the right. The head is painted in blue. ${ }^{11}$ Height, 8 inches. Dolon Nor, Tibet. (Cat. No. 130400, U.S.N.M.)

138. Kuan-Y in.-Porcelain, seated on a lotus around which is coiled a dragon; the right hand holds a child, the left rests on her knee, and on the sides are a male and female suppliant. Kuan-Yin, in Japan, Kuannon, her full name being Kuan-Shai-Yin, signifying, "a being who hears or perceives the cries of man," is in both countries the goddess of mercy and the female transformation of Avalokitesvara ("the one who looks down from above," namely, upon suffering humanity with compassion), the emanation or contemplation (dhyani) Bodhisattva of Amitabha, of whom Gautama Buddha was the earthly embodiment. Avalokitesvara has, therefore, charge of the world until Gautama's successor, the next Buddha in the person of Maitreya appears. Kuan-Yin is bodily healer as well as conveyor of the souls to the Paradise of Amitabha in the "bark of salvation." Seven cases of distress are generally specified in which she is ready to extend her hand of mercy: Dangers caused by the sword; fetters or chains; fire; water; demons; goblins; and an enemy. Sometimes danger by storm is added, to make four couples complete. As child bestowing, she is represented carrying a male infant in her arms and is invoked by women desiring offspring. Her worship is most widely extended in China and Japan. Height, $8 \frac{1}{2}$ inches. Foochow, China. (Plate 60, Cat. No. 216026, U.S.N.M.) Gift of Gen. G. W. Bailey.

139. Kuannon.-Wood painted and decorated. Standing on a blue base, holding an infant in the left hand. Face, hands, bosom, and

11 "Copper is found both native and in the form of pyrites in Tibet, where it is wrought with uncommon perfection. Several localities are well known for their famous founderies, which supply the whole of the Buddhist east with statuettes of divinities. Lhasa has a special reputation for small figures in gilt copper, which are esteemed the more the smaller they are. The statuettes made by the monks and craftsmen of Tashilumppo are equally esteemed. Most of the bronze statuettes come from the workshops of the Tsang and Khams Provinces. The bronzes from the region last named are famous for the perfection of their execution in details and their wonderful patina."-Wincent A. Smith, A History of Fine Arts in India and Ceylon, Oxford, 1911, p. 198. 
infant are painted white, the lower dress, brownish green with broad gold border; the upper, blue. Height, 6 inches. Kobe, Japan. (Plate 61, Cat. No. 154824, U.S.N.M.)

140. Kuannon.-Lead, bronzed, standing in a shrine of plain wood on a green lotus, holding in her right hand a sort of scepter $(j u-i)$, in the left, the precious ball (mani). Height, $7 \frac{1}{2}$ inches. Shigisan, Jamato, Japan. (Cat. No. 150581, U.S.N.M.)

141. Kuan-Y in.-Wood, painted. Holding infant. Faces, hands, and feet are painted white; the dress, brown. Height, 6 inches. Foochow, China. (Cat. No. 216027, U.S.N.M.) Gift of Gen. G. W. Bailey.

142. Kuan-Yin (?).-Pewter, red lacquered and gilt. Seated in meditation. Height, $9 \frac{1}{2}$ inches. China. (Cat. No.311805, U.S.N.M.) Bequest of Miss Elizabeth S. Stevens.

143. Kuan-Yin.-Copper, silvered. Statuette without base. The hands are wrapped in the voluminous folds of the dress, which, however, do not conceal the necklace with three pendants. The veil is drawn over the head and hangs down behind. Height, $4 \frac{1}{2}$ inches. China. (Cat. No. 311808, U.S.N.M.) Bequest of Miss Elizabeth S. Stevens.

144. Tshen-ju-Kuannon (thousand-handed Kuannon).--Relief of indurated clay, representing the goddess with many arms standing on a lotus. The distinctive attribute of the goddess, namely, mercy, is illustrated in this realistic manner by an image with many hands that are ever ready to help the needy. Height, 3 inches. Kobe, Japan. (Plate 62, fig. 1, Cat. No. 116220, U.S.N.M.)

145. Kuannon.-Wooden statuette painted and gilt, with six arms seated in lacquered shrine. Height, 4 inches. Japan. (Plate 62, fig. 3, Cat. No. 154272, U.S.N.M.)

146. Kuanti, Chinese god of war. - Sandal wood, carved. Standing on a mythical animal with two attendants, Kuanti, one of the deities of Taoism, was admitted into the temples of pacificistic Buddhism because as god of war he was considered as a valuable champion to enlist on the side of the true religion, and also because he was the tutelary deity of Manchu dynasty. Height, 5 inches. China. (Plate 62, fig. 2, Cat. No. 158284, U.S.N.M.)

147. Kuanti, Chinese god of war.- Wood, carved, painted, and gilded. Height, 28 inches. China. (Cat. No. 158312, U.S.N.M.)

148. Kuanti.--Relief carved of basaltic lava, with an inscription in intaglio. Height, 15 inches; width, 9 inches. Yokohama, Japan. (Cat. No. 75060, U.S.N.M.)

149. Tien-How.- Indurated clay. Woman seated, holding in her right arm an infant, in the left hand a lotus. Originally a Taoist divinity, the "queen of heaven," Tien How is worshiped in China as the mother of Buddha, whom she had miraculously conceived. She 
laid her cloak upon an island when she bathed in the sacred Ganges. On returning she found a lotus bud in the garment and, having eaten it, she conceived Buddha. Perhaps it was this divinity which gave rise of the coordination of Avalokitesvara with Kuan-Yin. Height, $4 \frac{3}{4}$ inches. China. (Cat. No. 130815, U.S.N.M.) Gift of Mrs. J. G. Bruff.

150. Maitreya.-Wood lacquered and silvered. Seated in meditation. Maitreya is the Bodhisattva of Gautama Buddha and the next and last Buddha to appear on earth during the present worldage (kalpa). He is the only Bodhisattva known to southern Buddhism (Burma, Ceylon, Siam). He is sometimes represented seated in European fashion, that is, with the legs let down, with the attributes of a vase (of ambrosia) and a wheel and lotus. Height, $9 \frac{1}{8}$ inches. Laos, Further India. (Cat. No. 217582, U.S.N.M.)

151. Maitreya (?).-Wood. Seated figure on a throne, wearing a crown, with the feet resting on a footstool. The right hand is resting on the knee, the left on the breast, and beneath it is a carved mask of a monster. Height, 10 inches. China. (Cat. No. 216029, U.S.N.M.) Gift of Gen. G. W. Bailey.

152. Jambyang (Sanskrit, Manjusri).-Bronze, gilt and polished. The name Manjusri means something like "having a lovely brilliance." $\mathrm{He}$ is the Bodhisattva of the celestial Buddha Akshobhya, and is the representative of transcedental wisdom. He is represented seated, holding in his right hand the sword of knowledge with which he cleaves the clouds of mental darkness. His other attribute is a book which rests upon a lotus rising behind his left arm. The high diadem is painted blue. His principal temple is at Wu-tai-shan in the Chinese Province of Shanhsi. Height, 8 inches. Lhasa, Tibet. (Cat. No. 130396, U.S.N.M.)

153. Bodhisattva (?).-Wood, carved, gilt and encrusted with pieces of colored glass. Standing on a base, holding a long stalk extending from the feet to above the head and probably terminated in a lotus bud, which is broken away. The robe, richly carved with bands of floral designs and beaded lines, reaches down to the feet, ending in a train behind. Over this is a short, closely fitted coat, descending to the hips, while from the arms hang folded scarfs. The head is covered with a diademed cap, from which rises a conical crown. The rather small ears have red stones attached to the lobes and are set in a triangular ornament. On the bosom is an ornament, formed of four lozenge-shaped pieces of glass with a boss in the center. Height, $19 \frac{3}{4}$ inches. Burma or Siam. (Plate 63, fig. 1, Cat. No. 311804, U.S.N.M.) Bequest of Miss Elizabeth S. Stevens.

154. Bodhisattva (?).--Bronze, cast and chased, gilt and polished. Standing on a base. The robe, descending to the feet, with a sort of waist held by a belt, is finely chased with floral designs. The 
hands, with the fingers bent and placed the right over the left, would indicate that had held something like a wand or scepter, which is missing. Height, $9 \frac{1}{2}$ inches. China or Mongolia. (Plate 63, fig. 2, Cat. No. 311807, U.S.N.M.) Bequest of Miss Elizabeth S. Stevens.

155. Drolma (Sanskrit, Tara).--Bronze, gilt and polished; Tara, the name meaning "savioress," is the female energy or counterpart (sakti) of the compassionate Avalokitesvara and like him she shows her gracious disposition towards mankind by her right hand being stretched out in the gift-bestowing gesture, while the left holds a lotus stalk. An ornamental fillet with a crest in the middle adorn the forehead. The other ornaments are large circular earrings, a double necklace, a long string of beads fastened between the breasts, richly studded armlets, bracelets, and anklets, and an elaborate girdle. The headgear is painted dark-green. Behind the left arm rises a lotus. Height, $6 \frac{1}{2}$ inches. Chamdo, Eastern Tibet. (Cat. No. 130395, U.S.N.M.)

156. Drolma (Sanskrit, Tara).-Brass. Similar to preceding No. 155. With a fig leaf-shaped halo. Crude workmanship. Height, $5 \frac{3}{4}$ inches. Thibet. (Cat. No. 311792, U.S.N.M.) Bequest of Miss Elizabeth S. Stevens.

157. Fudo.-Wood, carved and gilt. Seated in the easy position (lalita sana) on a rock, holding a sword in the right hand and a snare in the left, with a flame-shaped halo in open work, in a lacquered, gilt shrine. Fudo (the name meaning, "without movement") is considered as the Bodhisattra of Vairochana, the celestial reflex or meditation Buddha of Krakuchanda, the assumed first earthly (manushi) Buddha of the present world period. Fudo's function is to combat evil in the world, and his attributes are a sword and a snare to catch and bind the wicked and smite the guilty. In the funeral ritual of the Shingon sect of Japanese Buddhism a Fudo sword is placed in front of the celebrant in the belief that he takes charge of the soul after death. Fudo is also patron of soldiers. Height, $6 \frac{1}{2}$ inches. Japan. (Plate 64, Cat. No. 311,812, U.S.N.M.) Bequest of Miss Elizabeth S. Stevens.

158. Tamdrin, or Tamdin (Sanskrit, Hayagriva).-Bronze, gilt and polished, Hayagriva-Tamdrin is one of the eight dreadful gods, united by the Tibetans in the group of Dragshed ("terrible slayer"). They are Hindu or local Tibetan gods brought into the Buddhist system as protectors of the true faith against the demons of their several spheres. They are represented as beings of ferocious aspect, with broad and hideous heads, protruding tongues, and huge teeth. Their limbs are enormously strong, but short, and their bodies are misproportioned; they are surrounded with flames or smoke, and on their forehead they bear a third eye (the "eye of wisdom)." In the present figure Hayagriva-Tamdrin is represented kneeling on 
his left knee, with three faces of hideous expression, and on his head a crown of flames (painted red). Around his waist is a girdle of leaves, and a large rosary hangs around his neck. He has six arms. In his upper right hand he holds a snare to catch the demons, and in the lower an arrow; in his upper left hand is a three-leaved flower (?) and in his lower left a bow. The middle right hand which he holds before him has in it the vajra (Tibetan dorje), the thunderbolt of Indra, the Hindu god of the atmosphere; the middle left hand is empty, the thumb touching the second and third fingers, the index and little finger held extended. He is horse-necked and frightens the demons by his neighing. For this reason the Mongolians consider him protector of horses. Height, 8 inches. Lhasa, Tibet. (Cat. No. 130398, U.S.N.M.)

159. God of riches (Jambala or Kubera, Tibetan, Gunkar Yizin Norbu).-Bronze, gilt and polished. The god of riches is one of the Dragsheds (for which see No. 158). He also appears as one of the four world guardians (Lokapalas), who dwell around Mount Meru, the reputed center of the Buddhist world. He is three-faced, with a crown of flames (painted red), standing on two elephants. He has six arms adorned with anklets and bracelets. The middle hands are held before him with offerings in them. The upper right hand holds a vajra (dorje, the thunderbolt of Indra), the upper left a threeforked club, perhaps intended to represent the trisula, or trident, the scepter of the Hindu god Siva. The lower right a small hand drum (damaru), and the lower left a snare. Height, $4 \frac{1}{2}$ inches. Lhasa, Tibet. (Cat. No. 130399, U.S.N.M.)

160. Gandharva.-Wood, red lacquered and gilt. Human kneeling figure in the attitude of adoration, set on wings. The Gandharvas belong to the Devas, secondary deities or attendants. In the Hindu system, whence they were introduced into Buddhism, they are the musicians of Indra, who with their master serve and worship Buddha. They are sometimes represented with a human bust on the body of a bird, playing a musical instrument. Height, 6 inches. Laos, Further India. (Cat. No. 217607, U.S.N.M.)

161. Maha Upakut.-Wooden figure, lacquered and gilt. Represented with the hands pressed on the prominent abdomen, wearing a flat red cap in form of an open lotus and red garment thrown on the left shoulder. The Laos describe the Maha Upakut as a son of Buddha, who was born in the water of the river god. His skin is rough in imitation of a fish's scales. They believe that touching his figure after it has been dedicated to a temple will cure pains of the stomach. Height, 10 inches. Laos, Further India. (Plate 65, Cat. No. 217596 U.S.N.M.)

162-166. Maha Upakut.-Wood, lacquered and gilt. Similar to

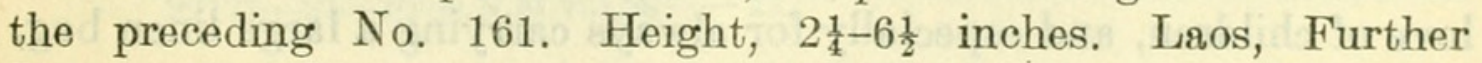
India. (Cat. Nos. 217597-217601, U.S.N.M.) 
167. Daikoku.-Wood, lacquered and gilt. Daikoku is one of the Japanese seven gods of good fortune (Shichi-fuku-jin), which are derived from Hinduism, Buddhism, Taoism, and Shintoism, and form a sort of popular appendage to Japanese Buddhism. They are, in the order of their popularity, as follows:

1. Daikoku (the "great black one") is Mahakala of the Hindus. But while the Hindu god is one of the most destructive and aweinspiring deities of the Hindu pantheon, his Japanese counterpart is the smiling god of wealth. $\mathrm{He}$ is usually represented as a sturdy figure habited in the ancient dress of a well-to-do Chinese burgher, with a flat cap. In his right hand he holds the magic hammer, a single stroke of which gives wealth, while his left hand grasps the mouth of a sack that is slung across his shoulder. He stands or sits upon a well-filled pair of rice bales. The mallet being the attribute of miners, and the rice the product of agriculture, are emblematic of the two principal sources of the wealth of ancient Japan. Sometimes he also carries a turnip. His picture is frequently found at the entrance door to the house.

2. Ebisu (the "stranger") is, notwithstanding his name, an indigenous product of Japan. He was the younger brother of the Shinto sun goddess Amaterasu (from whom the emperors of Japan derived their descent). He somehow incurred the displeasure of his family and was expelled to the western sea, where he spent his remaining life as a fisherman. He is, accordingly, represented with a fishing rod in his right hand and a fish (Pagrus cardinalis or major, which is considered by the Japanese the most delicious provision on the table). $\mathrm{He}$ is the patron of merchants and tradesmen and is usually in the company of Daikoku, the patron of the farmers.

3. Benzaiten (popularly abbreviated to Benten) is identified with Sarasvati, the spouse of Brahma, the Hindu goddess of eloquence and learning, and her character has remained the same in Japan. She is also the popular goddess of love and beauty and everything that adorns life. In Hindu mythology she is depicted as riding on a peacock as her vehicle (vahan). In Japan she is often represented as standing or sitting on a dragon and holding a musical instrument.

4. Bishamonten (Bishamon) is the Hindu Kubera or Vaisravana, the god of riches and the Buddhist Maharaja of the northern quarter of Mount Meru (see above under No. 159). In Japan he is the god of strength and wealth, but also the patron of knowledge. He is usually represented as a stately knight, holding a model of a castle or tower and a spear and standing on a conquered foe, which symbolise his function as guardian warrior god.

5. Hotei ("linen bag") is believed to have been a Chinese priest who lived in the tenth century A. D., celebrated for his fatness, his love of children, and especially for always carrying a large linen bag, 
from which his name is derived. In China he is worshiped under the name of Pu-tai as an incarnation of Maitreya, the Buddha of the future. He is a sort of a Japanese Santa Claus, the god of mirth and laughter.

6. Jurojin ("old venerable man") is of Chinese origin. $\mathrm{He}$ symbolizes longevity. His attributes are a stag or crane, both (together with the peach and tortoise) being emblems of longevity.

7. Fukurokuju ("bliss, wealth, longevity"). His most prominent physical mark is his tall head, being at least twice as long as his face, as if an ordinary-sized cranium was not large enough to hold all his virtues, knowledge, and happiness. He is the companion of Jurojin, and their names and attributes are often interchanged.

Height of the Daikoku figure, 13 inches. Japan. (Plate 66, Cat. No. 130458, U.S.N.M.)

168. Daikoku.-Lead, silvered. Height, 3 inches. Kobe, Japan. (Cat. No. 154827, U.S.N.M.)

169. Ebisu.-Lead, silvered. Height, 3 inches. Kobe, Japan. (Cat. No. 154826, U.S.N.M.)

170. Juroïn.-Sitting beside a stag. Bronze, black lacquered. Height, $2 \frac{1}{2}$ inches. Japan. (Cat. No. 311809, U.S.N.M.) Bequest of Miss Elizabeth S. Stevens.

171. Fukurokuju.-Bronze. Height, $6 \frac{3}{4}$ inches. China or Japan. (Plate 67, Cat. No. 311811, U.S.N.M.) Bequest of Miss Elizabeth S. Stevens.

172. Fukurokoju.-Miniature mask, brass, gold plated. Height, $1 \frac{1}{2}$ inches. China or Japan. (Cat. No. 311863, U. S.N.M.) Bequest of Miss Elizabeth S. Stevens.

\section{THE BUDDHIST SCRIPTURES (DHARMA).}

The sacred books supposed to embody the word of Buddha, are considered by Buddhists as forming the second member of the Triratna - the three precious ones-to whom the pious Buddhist daily takes his refuge. The books themselves receive divine honors. They are held materially sacred, are placed in high places and worshipped.

The two main divisions of Buddhism, the Hynay ana and Mahayana, or the southern and northern schools, respectively (compare the introduction, p. 294), have different canons of scriptures. The southern canon is written in the Pali language, and contains on the whole the older and purer exposition of Buddha's doctrines, though it already shows a considerable development. The scriptures of the Mahayana, or northern school, which are written parts in Sanskrit and in a mixed dialect of Sanskrit and Middle Indian or the Gatta dialect, parts in Chinese, Tibetan, Mongolian, and Japanese, are in 
their contents more or less influenced by Hinduism, and contain not only what is found in the Pali scriptures but a great deal more. The southern canon is about twice as large as the English Bible, and is assumed to have been fixed in the third century B. C., and reduced to writing in Pali in the first century B. C. The northern canon is about a hundred times larger than the Pali canon. Thus, the Chinese scriptures are seven hundred times the amount of the New Testament, comprising 5,000 books, which represent 1,662 differen works. The Tibetan canon, called Ka-gyur (Kan-jur) contains 100 or 108 volumes of about 1,000 pages each and representing 1,083 different works.

The Buddhist scriptures go by the name of the Tripitaka (three baskets) because when the scholars classified the sacred writings, wnich were written on palm leaves, the books were put into baskets. Another explanation expresses the idea of how the scriptures were handed down from one generation to another. In the Orient it is a common custom to have workmen stationed in a line who hand from man to man a series of baskets filled with something to be removed from one place to another. In the case of the scriptures it expresses figuratively the long line of teachers who handed down to generation after generation the teachings of the founder.

173. Sacred writings of the southern Buddhists (Tripitaka).Printed edition in 39 volumes, in the Pali language (the sacred language of the southern Buddhists) and in the Siamese alphabet. The three "baskets" contain:

1. The Vinaya-pitaka, the collection of rules and precepts especially intended for the monks (vols. 1-8).

2. The Suttanta-pitaka, or Sutras, containing discourses, proverbs, hymns, and legends for general instruction (vols. 9-28).

3. The Abhidhamma-pitaka, devoted to the metaphysics of Buddhism (vols. 29-39).

\section{Bangkok, Siam. (154,989.)}

Presented by His Majesty Somdetch Phra Paramindr Maha Chulalonkorn Phra Chula Chom Klao, King of Siam, in commemoration of the twenty-fifth anniversary of his reign, March 20, 1895.

174. Prajna Paramita (Tibetan, Shirab).--Tibetan manuscript, written on 366 ornate cardboards, consisting of several layers of paper pasted together and varnished over with a black pigment, in gold letters, and held between two covers of lacquered and gilt wood. The Prajna Paramita, or "transcendental wisdom," properly, "the means of arriving at the other side of wisdom," consists of mythical discourses attributed to Buddha and addressed mostly to supernatural hearers on the Vulture's Peak at Rajagriba (the modern district of Patna, Bengal). It is the most sacred book of the Mahayanist scriptures. It is ascribed to Nagarjuna, a converted Brahmin 
philosopher to Buddhism, who possibly lived in the second century A. D., and who is counted the fourteenth of the twenty-eight patriarchs of the Mahayana hierarchy. Nagarjuna alleged that he received the book from the Nagas, who dwell in the ocean (for which see above under No. 40), and they received it from the mouth of Gautama and kept it until a generation arose which was capable of understanding it. Height, 10 inches; width, $17 \frac{1}{2}$ inches; thickness, 7 inches. Tibet. (Cat. No. 237929, U.S.N.M.) Collected by Lieut. Col. L. A. Waddell, archeologist of the Indian Government expedition to Tibet in 1904-5, and presented by the Government of India.

175. Printing block of wood in Manchu and Chinese characters.From the library of the Temple of the Colossal Buddha in the palace grounds of Peking. Length, 25 inches; width, 8 inches. Peking, China. (Cat. No. 222152, U.S.N.M.) Lent by Miss Eliza R. Scidmore.

III. THE BUDDHIST CONGREGATION (SANGHA).

1. SAINTS AND PRIESTS AND THEIR APPURTENANCES.

176-177. Pair of arhats. - Wood, lacquered. Seated figures. The term arhat (Chinese, lohan, Japanese, rohan) is in a specific sense applied to the original disciples of Buddha, the apostles, who are variously counted from 10 to 500. More generally it designates a disciple or follower of Buddha who has attained the highest degree of perfection and completed the chain of existence so that he need not be born again. In a still wider sense it is applied to any virtuous and learned saint. The chief apostles or missionaries are usually provided with some attribute or emblem, such as a book or scroll, a fly whisk and vase, as seen on these figures, a jeweled snare, a crown, and so on, and receive worship in the temples. Height, $19 \frac{1}{2}$ inches. Tokio, Japan. (Plate 68, Cat. No. 130460, U.S.N.M.)

178. Arhat.-Bronze, gilt. Seated figure, with hands joined in the attitude of veneration. Height, 4 inches. Laos, Further India. (Cat. No. 217668, U.S.N.M.)

179. Arhat.-Wood, red lacquered and gilt. Kneeling figure, with hands joined. Height, $4 \frac{3}{4}$ inches. Laos, Further India. (Cat. No. 217575, U.S.N.M.)

180. Arhat.--Bronze. Seated figure, with hands raised in reverence. The inscription on the base states that it was dedicated in the year 1151 of Buddha. Height, $4 \frac{1}{2}$ inches. Laos, Further India. (Cat. No. 217513, U.S.N.M.)

181. Arhat.-Wood, lacquered and gilt. Kneeling figure, with hands folded in adoration. Height, $5 \frac{1}{4}$ inches. Laos, Further India. (Cat. No. 217562, U.S.N.M.)

182. Arhat.-Wood, lacquered and gilt. Kneeling figure, holding begging bowl, or medicine vase, with both hands of the outstretched 
arms. Height, $6 \frac{3}{4}$ inches. Laos, Further India. (Cat No. 217563, U.S.N.M.)

183. Tibetan saint, supposed to represent Ch'os-bjin jamba.-Bronze, gilt and chased. Seated in meditation, clothed in a mantle falling over the arms. The base is chased with floral designs. Height, $7 \frac{1}{4}$ inches. Kumbum, Sifan, near the western frontier of China. (Cat. No. 167270 , U.S.N.M.)

184. Holy man, probably Chinese saint.-Bronze, gilt. Seated in western fashion. Height, $6 \frac{1}{2}$ inches. Kumbum, Tibet. (Cat. No. 167269, U.S.N.M.)

185. Saint.- Terra-cotta figurine, seated, holding begging bowl in front. Height, $3 \frac{3}{4}$ inches. Tibet (?). (Cat. No. 311810, U.S.N.M.) Bequest of Miss Elizabeth S. Stevens.

186. Maha Krachai.-Porcelain figure of a saint, apparently of Chinese make. It is called by the Laos Maha Krachai and regarded by them as a learned saint. It is the only figure outside of Buddha found in Laos temples. Height, 4 inches. Laos, Further India. (Cat. No. 217626, U.S.N.M.)

187-190. "Neophytes."-Wood, red lacquered and gilt. Kneeling figurines with heads bowed to the ground and joined hands to the right side of the head in the attitude of adoration. Height, $2 \frac{1}{2}$ to 3 inches. Laos, Further India. (Cat. Nos. 217571-217574, U.S.N.M.)

191. Chinese Buddhist ecclesiastic.-Wooden seated statue, clad in the regulation dress of Buddhist monk. These consist (1) of the lower garment (antavarasatta), fastened by a girdle at the waist; (2) the middle robe (uttarasanga); (3) the outer shawl (sanghati), a strip of yellow cloth, 10 to 20 feet long and 2 to 3 feet broad. It is thrown over the left shoulder and passed under the right arm, leaving the right shoulder bare. But both shoulders and the chest are covered by an inner vest on entering the house of a layman. And over all is thrown a plaited cloak or cape, crescentic in shape. Height, 50 inches. China. (Plate 69, Cat. No. 127562, U.S.N.M.). Gift of the Chinese Centennial Commission, 1876.

192. Buddhist priest's robes.-Consisting of strips of yellow cloth. Ceylon. (Cat. No. 154979, U.S.N.M.)

193. Buddhist ecclesiastic.-Wood, painted. Seated in a chair in ceremonial robes. Height, 40 inches. China. (Plate 70, Cat. No 216028, U.S.N.M.) Gift of Gen. G. W. Bailey.

194. Buddhist ecclesiastic.-Wood, painted and gilt. Seated in ceremonial robes on a carved and gilt double base. Height, $3 \frac{1}{2}$ inches. Kobe, Japan. (Plate 71, fig. 1, Cat. No. 154823, U.S.N.M.)

195. Buddhist monk.-Model carved in wood. Represented with fan, staff, beads, and vessels for receiving rice, all of which a Buddhist monk carries when begging. Height, $5 \frac{3}{4}$ inches. Burma. (Plate 71 fig. 2, Cat. No. 176647 U.S.N.M.) Gift of M. A. Tribolet. 
196. Miniature of a Tibetan Buddha.-Statuette of bronze, gilt, inclosed in a small shrine. Height of image, $2 \frac{1}{2}$ inches; of shrine, $3 \frac{1}{2}$ inches. Shanghai, China. (Plate 71, fig. 3, Cat. No. 158309, U.S.N.M.)

197. Kammaracham.-Ordination service of a Buddhist monk. Manuscript written on strips of palm leaf, written on both sides in the Pali language in the Laos characters. The writing is done by means of a sharp stylus, and then ink is rubbed over so as to make the markings with the stylus visible. Gilt on the edges, inclosed by two wooden tablets secured by a cord passing through them. At the end of the cord is a fish carved of wood and a bundle of bamboo rings. The fish as a symbol was adopted by the Buddhists from Hinduism. In Hindu mythology a fish, that was the disguise of Brahma or Vishnu, was the savior of Manu (the Hindu Noah) in the great flood. The first incarnation of Vishnu was in the form of a fish (the matsya avatar), and generally is the fish considered symbol of good luck and favorable omen. In the late Mahayana texts Buddha is compared to a fisher. Length, $23 \frac{1}{2}$ inches; width, $2 \frac{1}{2}$ inches. Laos, Further India. (Cat. No. 217669, U.S.N.M.)

198. Japanese Vajra.-Bronze. The vajra (Tibetan, dorje), literally, diamond, or that which is indestructible, symbolic of the true doctrine which can not be destroyed, is the ritual scepter or wand of Mahayana or northern Buddhism. It is originally the thunderbolt of Indra, the Hindu god of the atmosphere, only that the points of the darts are closed. "The Nepalese scriptures say that a contest once occurred between Buddha and Indra, in which the latter was defeated, and had wrested from him his chief and peculiar instrument of power, the vajra or thunderbolt, which was appropriated as a trophy by the victor, and has ever since been adopted by his followers as the favorite emblem of their religion" 12 The Tibetans believe the dorje to have fallen from heaven and to have alighted in a monastery at Lhasa, where the original is still retained. It is called in Tibetan serapun-dze. An annual festival has been established in its honor and is one of the principal religious fetes. ${ }^{13}$ The three-pronged vajra is called by the Japanese san-ko; the five-pronged, go-ko; the single-pointed vajra which is in use in Japan is called do-ko. Length, $5 \frac{3}{4}$ inches. Japan. (Cat. No. 130390, U.S.N.M.)

199. Japanese Vajra.-Bronze. Length, $5 \frac{1}{1}$ - inches. Japan. (Cat. No. 167172 , U.S.N.M.)

200. Tibetan Dorje.-Bronze. Length, $4 \frac{3}{4}$ inches. Tibet. (Cat. No. 167268, U.S.N.M.)

\footnotetext{
12 William Woodville Rockhill, Notes on the Ethnology of Tibet. Report of the U.S. National Museum, 1893 , p. 740.

18 Edward Paske, Journal of the Archaeological Institute of Great Britain and Ireland, vol. 8, p. 202.
} 
201. Temple bell (Tibetan, drilbu).-Bronze. On the outer surface near the handle are in relief eight mystic syllables. The handle is cylindrical and has a head, representing the Dharma (doctrine), surmounted by a dorje. The bell is used in the performance of daily services, and the great lamas are often represented with a bell in the hand. This bell was made in Derge, which country is famous for the clear-toned bells cast there. Tibet. (Cat. No.131011, U.S.N.M.)

202. Temple bell.-Bronze. Similar to the preceding No. 201, less the head of Dharma on the handle. Monastery of Dolon nor, eastern Mongolia. (Cat. No. 130389, U.S.N.M.)

203. Vajra.-Bronze. Similar to No. 198. Length, $4 \frac{1}{2}$ inches. Japan. (Cat. No. 77137, U.S.N.M.)

204. Vajra.-Copper. Six-pronged, with one prong in the middle. Crude casting. Length, 6 inches. Shanghai, China. (Cat. No. 158311, U.S.N.M.)

205. Vajra.-Brass. Eight-pronged, with one prong in the middle. Length, $4 \frac{3}{4}$ inches. Probably China. (Cat. No. 311802, U.S.N.M.) Bequest of Miss Elizabeth S. Stevens.

206. Vajra-dagger (Tibetan, phurbu).-Bronze. The three-angular dagger is set into an animal's (elephant's (?)) head. The central portion is in form of a vajra, and the hilt end is terminated by a triple demon's head and surmounted by a horse's head, representing Tamdrin or Hayagriva (for which see above No. 158). It is used in incantation to stab the demons. Length, $7 \frac{3}{4}$ inches. Tibet. (Plate 72, fig. 1, Cat. No. 311803, U.S.N.M.) Bequest of Miss Elizabeth S. Stevens.

207. Tip of a mendicant's alarm staff (hikila, Tibetan, khargsil).Consisting of a socketed brass bar with a circular loop on which are strung six jingling rings. It is carried by mendicant monks to drown out by its jingling worldly sounds, and to warn off small animals, lest they be trod upon and killed. Height, $4 \frac{3}{4}$ inches. Probably Tibet. (Plate 72, fig. 2, Cat. No. 311791, U.S.N.M.) Bequest of Miss Eliz. abeth S. Stevens.

Prayer wheels.-The prayer wheel (Tibetan, mani chos kor) is a cylinder of metal, or, in the larger wheels, of wood or even leather, through which runs an axis prolonged below to form a handle. Around this axis are rolled, one on top of the other, sheets of paper or leaves of a book inscribed with some formula or spell. The sheets are wound on the axis from right to left, and the wheel when set in motion must revolve in the opposite way, so that the writing passes in front of the person turning the wheel in the way in which it is to be read; that is, from left to right. A piece of metal attached by a small chain to one side of the barrel facilitates the turning of it. Each complete revolution of the wheel counts as one repetition of 
all the prayers contained in the cylinder. The prayer wheel is used especially by the Buddhists of Tibet, and the most usual invocation inscribed on the rolls in prayer wheels consists of the words: "Om! mani padme! Hum," which is rendered: "Hail, jewel in the lotus." The repetition of this formula is the most common mode of praying met with among the Mongols and Tibetans. It is addressed to Avalokitvsvara (Padmapani), who appeared from out of a lotus for the deliverance of mankind. By the Tibetans he is held in special veneration as the protector and patron of Tibet, and is being incarnated in the Dalai Lama, the head of Tibetan Buddhism. Prayer wheels are placed in the entrance to temples and houses, to be turned by each person passing by it, on gables of houses, or over the hearth, where they are twirled by the wind or smoke. Sometimes a wheel is fixed to the bed of a stream and kept in motion by the current, thus praying night and day for the owner. Besides the small handprayer wheeis, usually measuring from 3 to 5 inches in height and from 2 to 3 inches in diameter, there are large machines set up in temples and monasteries, which are sometimes 30 or 40 feet high and 15 or 20 feet in diameter. In these are placed a collection of the canonical books of lamaism (ka-gyur, see p. 322), and by means of bars fixed in the lower extremity of the axis of the barrel it is put in motion. It is a materialistic putting into practice of the symbolical phrase "Turning the wheel of the law."

208. Small Stationary Prayer Wheel.-Bronze. The axis projects above the top, so that it may be put in motion without removing it from the stand on which it rests. It is adorned with a raised ornamentation of the dorje and an invocation in Nepalese Sanskrit characters, while the top of the cylinder is ornamented with a wheel, and the bottom with four dorjes. Tibet. (Cat. No. 130393, U.S.N.M.).

209. Hand Prayer Wheel.-Bronze. The top is decorated with a silver wheel, studded with coral and turquoise beads. The bottom has four dorjes, and on the sides is the six-syllable spell in Landza characters in silver. Bands above and below are decorated with dorjes and lotus flowers, respectively. The axis terminates in a pineapple-shaped knob of silver. Tibet. (Cat. No. 130392, U.S.N.M.)

210. Prayer Wheel.-Bronze. The top is dome-shaped. The barrel is divided into two compartments by a ridge, which is decorated with coral and turquoise beads. Darjeeling (on the border of Tibet), India. (Cat. No. 74494, U.S.N.M.)

211. Strip of Chinese Paper.-On which the formula "Om, mani padme hum" is nearly 400 times repeated in print. As about 100 of such sheets can be wrapped in the cylinder, a revolution of the wheel would be equivalent to repeating the formula 40,000 times. Tibet (Cat. No. 131014, U.S.N.M.) 
212. Prayer wheel.-Bronze. Similar to the preceding, No. 210. The bottom is decorated with scroll patterns. Darjeeling, India (Cat. No. 74493, U.S.N.M.)

213. Prayer wheel.- The barrel of bronze is divided by a band of brass into two compartments, which have the invocation. Top and bottom, as also the pineapple-shaped knob on top and the bead on the side, are likewise of brass. The top is in shape of a fluted dome; the bottom is decorated with four dorjes, all in repousse. Probably Tibet. (Cat. No. 311794, U.S.N.M.) Bequest of Miss Elizabeth S. Stevens.

214. Prayer wheel.-Bronze. Resembling the preceding. Leh, Ladak. (Cat. No. 175152, U.S.N.M.) Gift of W. L. Abbott.

215. Prayer wheel.-Bronze. Flat top; otherwise similar to the preceding. Leh, Ladak. (Cat. No. 175153, U.S.N.M.) Gift of W. L. Abbott.

216. Prayer wheel.-The barrel is of felt covered with coarse woolen cloth. An iron pivot runs through the barrel and fits in a roughly carved wooden handle. The cylinder is covered with a piece of red cotton cloth, to the corners of which are attached glass beads. Tibet. (Cat. No. 167169, U.S.N.M.)

ROSARIES.

The rosary, like the prayer wheel, is especially peculiar to the northern, or Mahayana, school of Buddhism, with its belief in the merit and efficacy of meditation and in the potency of repeating mystic spells and formulas. The Buddhist full rosary is composed of 108 beads, and this number is given a symbolic signification. The number 108 is said to correspond to a like number of mental conditions, or sinful inclinations, which are to be overcome by the recitation of the beads. The number 108 generally plays a great part in the tradition and philosophy of Buddhism: 108 Brahmans were summoned at Gautama's birth to foretell his destiny. The Burmese footprints of Buddha have sometimes 108 divisions. The Ka-gyur, the Tibetan canon of scriptures is composed of 108 vloumes, and the white pagoda at Peking is surrounded by 108 columns. In Japan, on the festival of the dead (bommatsuri or bonku), which is celebrated from the 13th to the 15th of July, 108 welcome fires (mukaebi) are lighted along the shores of the sea or lake or river by which a city or village is situated.

The full rosary of 108 beads is usually divided by three beads of a different size or material into four groups of 27 beads each. The two ends of the string before being knotted are passed through three extra beads, called "retaining beads," or "union holders," as they keep the proper rosary beads in position and indicate the completion of a cycle. They symbolize the Buddhist triad-the Buddha, the 
doctrine (dharma), and the community (sangha). Attached to the main string are two small pendant strings, having each 10 smaller beads. These pendants are used as counters to keep count of the number of times the rosary is said. A bead of one pendant string is slid down on completion of a single recital of the rosary, while the beads of the second note each 10 repetitions. They thus serve to register the utterance of 108 multiplied by 10 multiplied by 10 , equaling 10,800 prayers or formulas. Sometimes there are two additional pendants.

Alongside of the full rosary of 108 beads, employed'by the monks, there are in vogue rosaries of 18 and 16 beads, representing, respectively, the 18 lohans or chief disciples of Buddha counted by the Chinese, and the 16 rohans of the Japanese. The common people, moreover, use indifferently rosaries with various numbers of beads.

The material of the Buddhist rosaries varies according to the taste, wealth, and rank of the owner. The commonest are made of seeds, wood, pebbles, shells, glass, or bone; the more costly of jade, turquoise, coral, amber, silver, and gold, and even of pearls and other gems. The countries in which the Buddhist rosary is most widely used are China, Tibet, and Japan. ${ }^{14}$

217. Chinese rosary (su-chu).-The 108 beads of the main string are palm-wood balls. The dividing and retaining beads are of silver, richly enameled, measuring $1 \frac{1}{2}$ inches in diameter. The three counter strings have each 10 beads, likewise of enameled silver but of smaller size, being only one-half inch in diameter. From the retaining beads is suspended a silk ribbon embroidered with small glass beads of diverse colors to represent the swastika and other symbols, with a silver enameled medallion, measuring $2 \frac{1}{4}$ by $1 \frac{3}{4}$ inches in the center, and terminating in an oblong or oval bead 2 inches long. Such an oval bead is also at the end of each of the three counter strings, each $1 \frac{1}{4}$ inches long. They are called the "four dewdrops," which they resemble, or the "disciple beads," or the "regents of the four heavens." They typify the emperor, father, mother, and the teacher, to whom a Chinese subject owes reverence and obedience. This rosary is the official necklace which used to be worn by dignitaries on state occasions. China. (Cat. No. 202869, U.S.N.M.) Gift of Yang Yu, Chinese minister to the United States, 1897.

218-20. Three Chinese rosaries.-Consisting of 108 globular beads made of black wood. Hoihau, China. (Cat. No. 154242, U.S.N.M.)

221. Chinese rosary.-Consisting of 18 olive-shaped beads, probably made of some wax or resin composition, each being carved into an image of one of the 18 lohans or saints. China. (Cat. No. 130388, U.S.N.M.)

14 Compare also "The collection of rosaries in the U. S. National Museum," by I. M. Casanowicz. Proc. of the U. S. National Museum, vol. 36, pp. 333-360, with pls. 21-30. 
222. Chinese rosary.-Consisting of 18 beads made of the fruit of the Trapa bicornis of China, which resembles a Buffalo's head with two blunt horns. China. (Cat. No. 5503, U.S.N.M.)

223. Tibetan rosary (trengwa, "string of beads").-Consisting of 108 disk-shaped shell beads, divided into four groups of 27 beads each by three red coral beads. The three retaining beads (do dzin) are a large spherical amber bead, a smaller disk-shaped one, and a conical one of coral. The four counter strings (drang dzin), with 10 silver beads on each terminate in various ornaments. This form of rosary is in common use among the lamas. The rosary in Tibet is not only an essential part of the outfit of the lamas, but is everywhere in appearance. Nearly every man and woman carries a rosary, holding it in the hand, or attached to the girdle, or wearing it around the neck as a necklace, or twisted around the wrist as a bracelet. Laymen also use it to assist in ordinary calculations, like the sliding balls of the Chinese, in their business transactions. Kumbum, Tibet. (Cat. No. 167271, U.S.N.M.)

224. Tibetan rosary.-Consisting of 108 disks cut from human skull, divided into four sections of 27 each by three larger disks of conch shell, with two retaining beads of amber and wood, respectively, but without counters. Such rosaries are especially used in the worship of Dorje jig-ch'e (Sanskrit, Yama), the king of the dead. Tibet. (Cat. No. 130387, U.S.N.M.)

225-6. Tibetan rosaries.-Made of small disks of rosewood, with red coral beads as dividers. It has no counters, and the dividing beads, as also the three retaining ones, have to be counted to complete the number of 108 . Beads of reddish color, usually of red sandalwood, are used in the worship of the fierce Tamdrin (Hayagriva, see above No. 158), the demon patron of lamaism. Tachien-lu, China. (Cat. No. 167267, U.S.N.M.)

227. Tibetan rosary.-Consisting of 108 disks of yellow wood, with the dividing beads of the same material only slightly larger and thicker. It has only two retaining beads and no counters. Batang, China. (Cat. No. 131058, U.S.N.M.)

228-229. Tibetan rosaries.-Consisting of 108 spherical beads of yellow wood, without counters and with only one retaining bead. Said to have been brought from Lhasa, the holy capital city of Tibet. Ladak. (Cat. Nos. 178119-178120, U.S.N.M.) Gift of W. L. Abbott.

230. Japanese rosary ( $j i u-d z u$ ).-Consisting of 112 globular beads made of cherry wood. In the Japanese jiu-dzu the Buddhist rosary attained its highest development. The rosary of 112 beads (shozoki jiu-dzu), which is used by all sects in common, is divided by 2 large beads, called parent beads (oya-dama) into two equal parts. They are distinguished into the upper parent bead (ten-no oya-dama), 
also called father, sun, Buddha, and lower parent bead (chi-no oyadama), mother, moon, Bo, divine spirit, which inspired and perfected the enlightenment of Buddha. The ends of the string before being knotted are drawn through the 2 parent beads which have for this purpose a third opening. From the upper parent bead extend 2 pendant strings on which are strung 21 beads, smaller than those on the main string, in the following manner: Immediately above the large parent bead, on the left-side pendant string, is a solitary bead. Beyond this the strings are knotted. Then come 5 beads on each string, when they are again knotted. Still again there are another 5 beads on each pendant, which then terminates in an elongated bead, called dewdrop (tsuyu-dama). The use of the solitary bead is that in holding the rosary, with the upper parent bead uppermost, it should be in the left hand; this will insure a right signification to each bead during prayer. The collective name of these pendant beads is kami-deshi, superior disciples. Extending from the lower parent bead are 3 strings, on 2 of which are 5 small beads, called shima-desti, or inferior disciples, each terminating in a dewdrop bead, while the third has 10 small beads without a dewdrop. They are used as counters and are called kadzu-tori. The 4 dewdrop beads are also termed shi-ten-no, the four regents who are supposed to preside over the four quarters of the universe. The rosary thus represents symbolically the Buddhist pantheon. On the main string, at an interval of 7 beads on either side from the upper parent bead, are 2 beads, smaller than the others, and again, at an interval of 14 beads from these, on either side, are other 2 of the same kind. They indicate where a special invocation is to be uttered while the rosary is lifted to the forehead with a reverence.

A smaller rosary of 16 beads, corresponding to the Japanese rohans, or chief disciples of Buddha (analogous to the 18 lohans of the Chinese), is chiefly used by lay peoples on ceremonial and social occasions. Japan. (Plate 73, Cat. No. 130683, U.S.N.M.)

231-2. Two Japanese rosaries.-Consisting each of 112 globular beads made of plum-tree wood. The same as the preceding No. 230 . Japan. (Cat. No. 130683, U.S.N.M.)

233. Prayer beads (mak-nap).--Made of small black seeds, strung on a cord. The invocations repeated by the Laos by means of the beads are: Sabbe sangkara anicca, 300 times; sabbe sangkara dukkha, repeated 400 times; sabbe sangkara anatta, repeated 500 times. Laos, Further India. (Cat. No. 217666, U.S.N.M.)

234. Buddhist monks' begging bowl.- Spherical, of thin iron, with wooden base. Inclosed in an open work bag formed of bands of cotton, the ends of which serve as handles. To this cloth is secured a lacquered base. From the bottom hang models of the perquisites of a monk, namely, (1) the water strainer, used to exclude the small 
animals which might be found in the water from being killed; (2) a drum; (3) sandals; (4) steel and flint for striking fire; (5) vessel for pouring out water when performing acts of merit; (6) a shaving

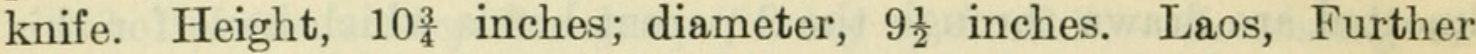
India. (Cat. No. 217664, U.S.N.M.)

235. Buddhist monk's begging bowl.-Old bronze, decorated with groups of rosette-shaped dots. Height, 4 inches; diameter, 8 inches. Japan. (Plate 74, Cat. No. 158321, U.S.N.M.)

236. Buddhist monk's begging bowl.-Earthenware, black lacquered. Height, 7 inches; diameter, 9 inches. Burma. (Cat. No. 129555, U.S.N.M.)

237. Buddhist monk's rice spoon.--Made of shell. Rice and fruit constitute the diet of Buddhist priests. They obtain these viands by begging from house to house, and an alms bowl, rice spoon, and fruit bag belong to the equipment of a Buddhist priest. They are bound to abstain from meat and intoxicating liquors, and from partaking of any food after midday. Length, 6 inches. Siam. (Plate 75, fig. 1, Cat. No. 127163, U.S.N.M.)

238. Buddhist monk's rice spoon.-Made of alabaster. Length, 4 inches. Tokio, Japan. (Plate 75, fig. 2, Cat. No. 127552, U.S.N.M.)

239. Fly flap.-Lacquered and gilt. The feathers are arranged in shape of a heart. "It is properly a screen, and is never used as a fan but to cover the face when presenting the alms bowl for alms so that the monk may receive the gift without knowing the giver. The Buddhist believes it is more blessed to give than to receive, and the merit belongs to the giver." Length, 26 inches; width, 14 inches. Laos, Further India. (Cat. No. 217665, U.S.N.M.)

2. RELIGIOUS EDIFICES AND THEIR PARAPHERNALIA.

240. The Wat Chang pagoda.-Model of wood, painted. Pagodas (the Burmese name for these structures; Singhalese, dagaba or dagoba; Sanskrit, stupa; Pali, thupo, whence Anglo-Indian tope; Nepalese, chaitya; Tibetan, chorten; Chinese, tah; Japanese, to) are religious structures the original purpose of which was to receive the relics of Buddha, or the remains of such of his disciples as distinguished themselves by piety or learning. But already in the early periods of Buddhism stupas were constructed ex voto, either for marking some important event in the life of Buddha and the history of Buddhism, or for decorating the monasteries and temples. In keeping with the original purpose of the pagoda, its earliest architectural style was derived from the tomb or tumulus. The earliest stupas are simple cupolas or hemispheres raised on a low basement, about half the diameter in height. With the exception of a small cell for the ashes or relics, these shrines were solid masses of bricks or stone. Gradually the plinth was increased until it rose from one to two diameters 
in height. The apex of the dome was usually surmounted by a disk placed horizontally, on which rose, as a terminal, an umbrella (tee), the emblem of royalty and state among eastern nations. Later the number of umbrellas was increased to $3,7,9,11$, and even 13 (always an odd number), placed one above the other. ${ }^{15}$

The pagoda of Wat Chang ("great monastery") is considered the most magnificent edifice of Bangkok, the capital of Siam. It is built of brick, and its outside plastering is wrought into a mosaic by means of porcelain of different colors set in it so as to form figures of elephants, griffins, demons, flowers, etc. From its broad octagonal base the bell-shaped structure rises in elegant tapering terraces, ending in a dome-shaped top, from which rises a sharp spire. In large niches upon the sides toward the summit are images of Buddha riding on elephants, and the whole building is lavishly adorned in both color and carving. It is assumed that the pagoda measures from the base to the tip of the spire about 250 feet in height. It is surrounded by smaller pagodas, shrines, monks' dwellings, flower and fruit gardens, ponds, grottos, and various stone statues. Dimensions, 3 by 3 by 3 feet. Bangkok, Siam. (Cat. No.158420, U.S.N.M.) Gift of the Marquis Visuddha, minister of Siam to England.

241. Chinese pagoda.-Model of wood. Consisting of nine stories, surmounted by a spire, called in Japanese kiu-do (nine rings), resembling a corkscrew such as may be used to uncork a columbiade. The form of the Chinese pagoda is probably derived from the spire ringed with umbrellas, described in the preceding No. 240, of the Hindu stupa. The umbrella-shaped roof is the main element in the Chinese paguda, the walls being mere screens, set between pillars. Each platform as it towers upward in decreasing size is supposed to denote a world. To the roofs of the various stories are attached small bells and tinkling copper leaves, which are swung and rung by the wind, to denote the eternal music of the spheres, and the carved balustrades and projecting eaves are emblems of the habitations of the happy beings dwelling in the supernal regions. Of the several stories only the first is used as a shrine for relics and images, while the others are hollow, with staircases leading up to the top.

The roofs are black lacquered, the railings and halls are red lacquered, the spire is gilt lacquered. Height, 5 feet by 23 inches square. China. (Cat. No. 313624, U.S.N.M.)

242. Pagoda.-Model of wood, lacquered and gilt. Consisting of three stories, surmounted by the nine-ringed spire (kiu-do), terminating in the jewel or sacred pearl, one of the three treasures or

${ }^{15}$ Compare "The Wat Chang Pagoda of Bangkok, Siam," by I. M. Casanowicz. Smiths. Misc. Coll. $\nabla$ ol. 47, pp. $273,274$. 
emblems of royalty in Japan. Height, 30 inches by 15 inches square. Japan. (Plate 76, Cat. No. 154965, U.S.N.M.)

243-245. The Temple Hongwanji and hair rope.-The great Hongwanji temple of the "True Sect" (Shin shu), at Kioto, Japan, was completed in 1895. Its dimensions are those of a western cathedral. Ninety-six massive pillars support the roof at a height of 126 feet. The timbers were all dragged from the mountain and lifted into their places by 29 immense ropes made of human hair, the voluntary offerings of innumerable women, which are still preserved within the precincts. Tokio, Japan. (Plate 77, fig. 1, plan of the temple Hongwanji; fig. 3, section of a hair rope, measuring 32 inches in length and $4 \frac{1}{2}$ inches in diameter, used in the erection of the temple; fig. 2, photograph of the ropes made of human hair. Cat. Nos. 150829-150831, U.S.N.M.) Gift of V. Marshall Law.

246, 247. Pair of Nios.-Models of wood, painted and decorated. The Nios or Niokongas ("the two bold golden kings") are usually placed on both sides of the lofty portal to a Buddhist temple in Japan as gatekeepers or guardians. They are the Hindu gods Brahma and Indra. They are represented naked, close-set, athletic figures, 10 or 12 feet high, with eyes and features distorted, painted vermilion red, wrestling against the powers of evil. Height, $16 \frac{1}{2}$ inches. Japan. (Plate 78, Cat. No. 166079, U.S.N.M.)

248, 249. Pair of Nios.-Models of wood, black lacquered. Height, 14 inches. Japan. (Cat. No. 130457, U.S.N.M.)

250. Buddhist temple.-Model of wood (in parts), red painted. Miniature copy of a Laos Buddhist temple, carved and set up by a priest, with the carvings, placement of the timbers, and the several parts of it, as the throne for the image of Buddha, the pulpit from which the scriptures are read, the Nagas on each side of the entrance, representing in every detail a copy of a Buddhist temple in Laos. Laos, Further India. (Cat. No. 217670, U.S.N.M.)

251, 252. Temple lanterns. - The lids of these two lanterns are of lacquered wood. The upper lid of each is provided with a bronze handle representing a dragon; the lower lid with bronze cocks. The lids have openings to admit a candle, for which an iron spike is provided on the bottom of the lower lid, upon which the candle is stuck. By raising the upper lid, the painted paper cylinder, which emits the light, is unfolded. The lanterns can either be hung up by the handles or suspended on poles which are passed through holes in both lids provided for that purpose. Height, $12 \frac{1}{2}$ inches; diameter, $13 \frac{3}{4}$ inches. Japan. (Plate 79 shows the lanterns opened; plate 80, fig. 1, exhibits the top; fig. 2 the bottom. Cat. No. 154967, U.S.N.M.

253. Temple lantern.-Copper. Hexagonal, with dome-shaped top in open work. Richly enameled in various colors and decorated with a profusion of floral designs. Height, 21 inches; diameter, 10 inches. Korea. (Cat. No. 154983, U.S.N.M.) 
254. Altar covering (Chinese, huan mun-tiao-kua).-Made of brown cloth, consisting of a center piece scalloped at the lower edge, with two side pieces which descended over the edge of the altar. Embroidered in gold with dragons and kilins (kirins), a mythical animal, pictured as resembling a stag in its body and a horse in its hoof, but possessing the tail of an ox and a parti-colored or scaly skin, and a single horn, having a fleshy tip, proceeds out of the forehead. The kitin is believed to exhibit great benevolence of disposition toward other living animals, and to appear only when wise and just kings or sages are born. Dimensions, 24 by $30 \frac{1}{4}$ inches. Shanghai, China. (Cat. No. 158307, U.S.N.M.)

255-258. Four altar coverings (Chinese, huan mun-tiao-kua).-Made of oblong pieces of brown cloth, with centerpieces of red cloth. The edges are embroidered in silk with floral designs, while on the body is an inscription in Chinese characters pasted on. Dimensions, 37 by $8 \frac{1}{4}$ inches. Shanghai, China. (Cat. No. 158307, U.S.N.M.)

259, 260. Pair of candlesticks.-Made of pewter in the shape of the Chinese character for longevity (sheu). The candles are stuck on the points at the top of the candlesticks, and lighted whenever a ceremony takes place. This is done in the temple service as well as in home worship. Height, 19 inches. Shanghai, China. (Plate 81, figs. 1 and 3, Cat. No. 158294, U.S.N.M.)

261. Incense burner (kong-po-to).- Made of pewter. On the front are in relief the Chinese characters for longevity (sheu) and bliss $(f u)$. Height, $7 \frac{1}{2}$ inches; length, $5 \frac{1}{2}$ inches; width, 4 inches. Shanghai, China. (Plate 81, fig. 2, Cat. No. 158295, U.S.N.M.)

262. Imitation candlesticks.-Wooden sticks with inserted points for candles to be stuck on them. Height, 8 inches. Japan. (Cat. No. 130678 , U.S.N.M.)

263. Censer.-Bronze. Supported on three legs formed of double volutes or spirals. The handles are in shape of dragons. The cover, in open work, is surmounted by a mythical bird perched on some mythical animal. The circumference is embossed with dragons and other monsters. Height, 10 inches; diameters, 6 and $4 \frac{3}{4}$ inches. Japan. (Plate 82, fig. 1, Cat. No. 220057, U.S.N.M.) Lent by Miss Eliza R. Scidmore.

264. Candlestick.-Bronze. Consisting of the figure of an emaciated ascetic holding a long dragon, the head of which rests on the base, while the tail terminates in a bowl for inserting a candle. Height, $6 \frac{1}{2}$ inches. Kobe, Japan. (Plate 82, fig. 2, Cat. No. 154825, U.S.N.M.)

265. Censer.-Brass. Height, $6 \frac{1}{2}$ inches. Kobe, Japan. (Cat. No. 254828, U.S.N.M.)

266. Censer.-Brass. The cover, in open work, is surmounted by a knob. Height, 4 inches. Japan. (Cat. No. 158314, U.S.N.M.) 
267. Censer.-Bronze. The cover, in open work is surmounted by a crouching mythical animal. Around the circumference are embossed trees with various birds perching in them. Height, $5 \frac{1}{2}$ inches; diameter, $3 \frac{1}{2}$ inches. Japan. (Cat. No. 311806, U.S.N.M.) Bequest of Miss Elizabeth S. Stevens.

268. Censer.-Bronze. Resting on three legs which are of animalheaded human figures. The lid is surmounted by a mythical animal. Height, $5 \frac{1}{4}$ inches; diameter, $4 \frac{1}{4}$ inches. Seoul, Korea. (Cat. No. 151618, U.S.N.M.)
269. Incense--Burma.
270. Incense.-Japan.
(Cat. No. 129531, U.S.N.M.)
(Cat. No. 130685, U.S.N.M.)

271. Flower vase.-Brass. Placed before Buddhist shrines. Height, 5 inches; diameters, 4 and $2 \frac{1}{4}$ inches. Probably China. (Cat. No. 158313, U.S.N.M.)

272. Lotus cup.-Bronze. Eight-fluted cup set in a quadruple eight-petaled lotus, with short stem and base of an inverted eightpetaled lotus. The lid has twenty perforations for inserting flowers. Height, $4 \frac{3}{4}$ inches; diameter, $2 \frac{1}{2}$ inches. India (?). Cat. No. 311796 , U.S.N.M.) Bequest of Miss Eizabeth S. Stevens.

273. Holy water vase (Tibetan, bumba or tsebum).-Made of brass heavily gilded in Persian shape, with a large spherical body and slender bent spout. The neck is short and narrow and terminates in a flaring mouth in shape like an overturned bowl. In the top of this is a small circular opening, in which a chased metal tube fits, reaching far down into the rase, and in its upper end a bunch of the sacred kusa grass and some peacock feathers. This instrument is the aspergil. The vase has a covering of silk fastened around the neck so as to completely hide the vase. Such coverings are put on most objects used in the temple worship, on the sacred images, books, etc., probably as a mode of honoring these sacred objects. The water used in these vases has a little saffron in it, and sometimes a little sugar. The vase is used especially in the ceremonies connected with the worship of Tsepamed (Amitayus), the Buddha of long life (see No. 137), and is called the vase of life. Height, $6 \frac{1}{2}$ inches. Kumbum, Tibet. (Cat. No. 130402, U.S.N.M.)

274. Libation bowl.-Made of a human skull with a lining of iron and an ornamented copper gilt rim fitting on it. The cover of copper gilt is finely and intricately chased and has on each side the mystic syllable om with an arabesque design surrounding it. The top of the cover is surmounted with four half vajras (dorjes) at right angles, a fifth and larger one forming the handle. The stand on which the skull rests is of gilt copper and triangular in shape. At the three angles are human heads, painted red, white, and green. The skull bowl is likewise used in the worship of Tsepamed, when it is filled with nectar brewed from chang. After 
the ceremony it is drunk by those present-a kind of a lamaist eucharist. The custom of using skulls as holy vessels, or even as eating bowls, is a very old one in Asia. Height, $9 \frac{1}{2}$ inches; diameters, 8 and $6 \frac{1}{4}$ inches. The specimen in the Museum came from Kumbum, Tibet. (Cat. No. 130384, U.S.N.M.)

275. Prayer banners (Chinese, yen-kou-fo, or tong hoan).-Consisting of five brass figurines holding small suspended banners of cloth. They are set up on the altar during recital of prayers for the souls of the dead, especially for the souls of those who failed to receive burial. Their number probably corresponds to the five earthly (manushi) Buddhas of the present age (kalpa), see p. 296, note 1). Height, $15 \frac{3}{4}$ inches. Shanghai, China. (Plate 83, Cat. No. 158303, U.S.N.M.)

276. Pair of prayer wands (Chinese, yen-kou tsi-tao).-Made of copper. Used in reciting prayers for the souls of the dead. They are placed crosswise one over the other. Length, $7 \frac{1}{8}$ inches. Shanghai, China. (Cat. No. 158310, U.S.N.M.)

277. Scent sprinkler.-Made of white metal in form of a longnecked narrow vase. Used at Buddhist funerals. Height, $14 \frac{1}{2}$ inches. Ceylon. (Cat. No. 154975, U.S.N.M.)

278. Temple sword.- On one side of the blade is incised a winding dragon, on the other a vajra (dorje). The scabbard is red and gilt lacquered, crossed by bands in red and black. The hilt is covered with shark skin and set on either side with bronze dragons. The lower end of the scabbard and the head of the hilt are framed in a marine animal (lobster?) of bronze. A sword is placed on the altar in front of the celebrant in the worship of Fudo (see above No. 157). Length, 45 inches. Japan. (Cat. No. 154969, U.S.N.M.)

279. Temple sword.-On one side of the blade is incised a dragon winding round a vajra (dorje), on the other, a vajra. The scabbard is decorated in cloisonne enamel on a blue ground with rosettes alternating in pale green and crimson red, with other floral designs between them. The hilt, which is in shape of a vajra, is decorated in champleve enamel. Used in the worship of Fudo (No. 157). Length, 23 inches. Japan. (Cat. No. 154968, U.S.N.M.)

280. Japanese prayer book.-Folded. This prayer book comes from the famous temple Mis-kru-saw in Japan. The temple is a resort for invalids, particularly for those having affections of the eye, and the prayers contained in this book are for special use in the temple. Japan. (Cat. No. 130676, U.S.N.M.)

281. Temple drum.-Hung in a lacquered wooden frame set on a four-legged support. On the flattened faces of the drum are painted in gold lacquer a bird and leaves. Drums or bells are put up in front of Buddhist temples, on which the priests strike to announce the 
hours of prayer. The worshippers also strike them to invite the presence of the deity. Drums are likewise used in Buddhist worship to accompany the chanting of the priests. Diameter of the bell, 16 inches; height, $7 \frac{1}{2}$ inches; height of the frame, 36 inches. Japan. (Cat. No. 168815, U.S.N.M.)

282, 283. Pair of temple drums.--Set on four-legged lacquered wooden stands and surmounted by cocks. The circumferences of the drums are covered with red cloth. On the flattened surfaces are painted three comma-shaped segments, the Japanese modification of the Chinese (and Korean) tah-gook, formed of two segments, the common representation of the yang and yin, the two first causes and great principles of the universe, or contrary influences, such as darkness and light, male and female, good and evil, etc. The figure also represents the Japanese magatama, or "crooked jewel," one of the emblems of sovereignty in Japan, As regards the cocks perched on top of the drums, Dr. John Ellerton Lodge, curator of Chinese and Japanese art in the Museum of Fine Arts of Boston, kindly communicated the following interesting story:

The familiar Japanese or Chinese design of a cock on a drum is intended to suggest a well-known story of the famous Emperor Yao, who is said to have ascended the throne of China in the year 2357 B. C. This enlightened monarch caused a drum to be placed in front of his palace gate, with the announcement that whoever had any complaint to make to the sovereign should come to the gate and beat upon the drum, thereby attracting the Emperor's attention. So wisely, however, did this ruler govern his people, that none ever came to enter a complaint, and in the course of time the fowls went to roost on the silent drum.

Height, 26 inches. Japan. (Plate 84, Cat. No. 159966, U.S.N.M.) 284. Wooden fish (Japanese, mokugio; Chinese, mo-yii).-Carved and red lacquered. Used as drum in Buddhist ceremonies. The shape is accounted for by the supposition that the fish is sleepless, keeping its eyes always open on account of the lack of eyelids and eyelashes. It is therefore an emblem of wakefulness and watchfulness in the striving after perfection. Height, 12 inches; length 18 inches. Japan. (Plate 85, front; plate 86, back. Cat. No. 150893, U.S.N.M.)

285. Wooden fish (Chinese, mo-yiii; Japanese, mokugio).-Carved, and painted red, with wooden mallet for striking it. Similar to the preceding No. 284. Height, $10 \frac{1}{2}$ inches; length, 14 inches. Shanghai, China. (Cat. No. 158296, U.S.N.M.)

286. Wooden drum (Chinese, siao-ku).-Shaped like two flat plates put together. It is carried by the priest in processions and struck on the side. Diameter, $7 \frac{1}{2}$ inches. Shanghai, China. (Cat. No. 155300 , U.S.N.M.)

287. The nine-toned bell (Chinese, chin yin-lo).-Made of copper. Consisting of 10 small gongs suspended in a screen or gate-like cabinet which is struck with a small stick as an accompaniment to prayer. 
Height, 24 inches; width, 22 inches. Shanghai, China. (Plate 87, Cat. No. 158305 , U.S.N.M.)

288. Small gong (Chinese, yin-to).-Made of copper in shape of a pan or flat plate, with a wooden carved handle. It is struck with a carved slender stick as introductory to prayers in Buddhist tem-

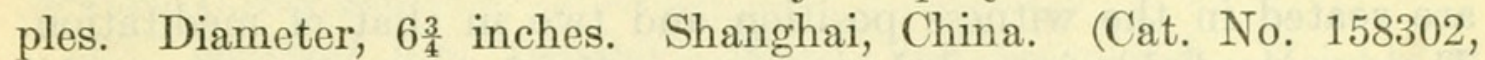
U.S.N.M.)

289. Small bell (Chinese, siao-chung).-Made of copper, suspended from a carved wooden frame. It has no clapper, but is struck with a stick on the outer circumference. Used in the temple service. Height, $14 \frac{1}{2}$ inches. Shanghai, China. (Cat. No. 158306, U.S.N.M.)

290. Inverted bell (Chinese, ch'm'g to).-Made of copper in form of a pot or kettle, sounded on the outer surface with a stick in Buddhist worship. Height, $4 \frac{1}{4}$ inches; diameter, 9 inches. Shanghai, China. (Cat. No. 158297, U.S.N.M.)

291. Small bell.-Made of copper. Suspended from a slender wooden carved stick which is held in the hand, while the bell is struck on the outer surface during the recital of prayers. Height, $1 \frac{1}{2}$ inches; diameter, $2 \frac{1}{8}$ inches. Shanghai, China. (Cat. No. 158308, U.S.N.M.)

292. Pair of large cymbals (Chinese, da-pa).-Made of brass. These cymbals are employed in the temple service, and also in private ceremonies, such as weddings, funerals, etc. They are supposed to have been introduced into China from India. Diameter, $9 \frac{1}{2}$ inches. Shanghai, China. (Cat. No. 158298, U.S.N.M.)

293. Pair of small cymbals (Chinese, siao-pa).-Made of brass. Used only in the temple service of the Buddhists. Diameter, 8 inches. Shanghai, China. (Cat. No. 158299, U.S.N.M.)

294. Pair of cymbals.-Made of brass. Used in Buddhist processions. Diameter, 7 inches. Laos, Further India. (Cat. No. 217504, U.S.N.M.)

295. Drum of skulls (Tibetan, damaru).-Made of two skulls attached together by a wooden disk cemented to them. A band of embroidered satin, decorated with elaborately knotted silk tassels of Chinese make, covers the disk between the two heads, by which the person using the drum may hold it in his hand, his thumb and forefinger being placed around the disk of wood between the drumheads. From the band are depending small knobs covered with cloth by short strings of such length that when the drum is sharply twirled around they strike the heads. Used by the lamas in the temple service in Tibet. Height, 3 inches; diameter, $4 \frac{1}{2}$ inches. Kumbum, Tibet. (Cat. No. 130385, U.S.N.M.)

296. Drum of skulls (damaru).-Painted in red and blue with heads of demons and skulls. The band around the wooden disk is

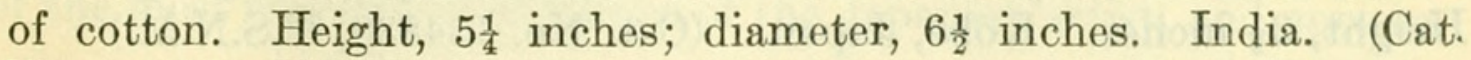
No. 153363, U.S.N.M.) 
297. Triratna, or the three jewels, namely, Buddha, the law_(dharma), and the congregation (sangha).-Wood, red and black lacquered and gilt. Represented by three columns set on a base. The center cone, which represents Buddha, issues from a lotus flower and in its circumference are set five Buddha figurines of ivory, of which three are seated in the witness position and two in that of meditation. They are probably intended to represent the five mundane (manushi) Buddhas of the present age. Between the petals of the lotus are carved five open lotuses and beneath them five leaves inlaid with pieces of shell and looking glass. The two side columns, which represent the law and the congregation, respectively, are carved in the shape of a closed lotus, flattened on one side, into which is inserted an ivory panel, representing Buddha standing in the gift-bestowing attitude. Height, 17 inches; width, $12 \frac{1}{2}$ inches. Laos, Further India. (Plate 88, Cat. No. 217501, U.S.N.M.)

298. Triratna.-Wood, lacquered and gilt. Representing Buddha standing in the center, while the two figures on the right and left are sitting. On the base is an inscription in Pali. Height, 14 inches; width, 7 inches. Laos, Further India. (Plate 89, Cat. No. 217585, U.S.N.M.)

299. Triratna.-Terra-cotta relief, finely molded. Buddha seated in the witness position in a niche, formed of a pointed arch resting on columns, an elaborate halo of rays rising above his head. The two smaller figures on his sides sitting in meditation. Height, $3 \frac{1}{4}$ inches; width, $2 \frac{1}{4}$ inches. Laos, Further India. (Cat. No. 217631, U.S.N.M.)

\section{MisCELlANEOUS: MAGIC, DivinATION, ETC.}

300. Lotus.-Model of wood. The lotus (Nelumbium speciosum) is, as has been said previously (No. 2), the favorite flower of India and invested with much symbolism. Among others, it is the symbol of purity. The lotus upon the lake seems to spring from the body of the waters without contact with the earth, and no matter how muddy the water may be, the lotus preserves its own purity undefiled. Thus Buddha is made to say: "Just as a lotus born in water, bred in water, overcomes water and is not defiled by water, so I, born in the world and bred in the world, have now overcome the world." The worshipers of Amitabha, or Amida, in China and Japan believe that each man while living on earth is represented in paradise by a lotus, which flourishes or languishes according to his spiritual condition. The saved dead (by faith in the invocation of Amitabha) are carried to the lake of lotuses where they are reborn with a spiritual body within the calyx of one of the lotuses. According to their merits, the lotus opens sooner or later. Some are imprisoned for thousands of ages within the closed calyx of their lotuses - a kind of painless purgatory. Height, $3 \frac{1}{2}$ inches. Kobe, Japan. (Cat. No. 154830, U.S.N.M.) 
301-2. Pair of mythical lions.-Bronze. Lions of metal or stone, sometimes of colossal size, are often placed at the entrance of Buddhist temples as protectors from evil spirits. They are also emblematic of Buddha who bears the epithet Sakyasimha, "the lion of the Sakya race." Length, 2 inches. Kobe, Japan. (Cat. Nos. 154831154832, U.S.N.M.)

303. Mythical lion (singto).-Wood, red lacquered. Height, 6 inches. Laos, Further India. (Cat. No. 217578, U.S.N.M.)

304-5. Pair of kirins (Chinese, kilin).-Wood, black lacquered and gilt. Standing on lacquered bases. For a description of the mythical kirin see above under No. 254. Height, $7 \frac{3}{4}$ inches. Japan. (Cat. No. 154296, U.S.N.M.)

306. Mythical animal, dog Fo (?).-Wood, painted brown with gray spots, lacquered and gilt. Height, 27 inches; length, 32 inches. China or Japan. (Cat. No. 313625, U.S.N.M.)

The following small collection of bronze animal figurines from Laos may be votives or weights:

307. Bronze dog.-Height, $\frac{3}{4}$ of an inch. Laos, Further India. (Cat. No. 217551, U.S.N.M.)

308. Bronze monkey. - Height, $\frac{3}{4}$ of an inch. Laos, Further India. (Cat. No. 217552, U.S.N.M.)

309. Bronze zebu, standing on base.-Height, $1 \frac{3}{8}$ inches. Laos, Further India. (Cat. No. 217547, U.S.N.M.)

310. Bronze zebu, couchant.-Height, three-fourths of an inch. Laos, Further India. (Cat. No. 217548, U.S.N.M.)

311. Bronze cow (?).-Height, three-fourths of an inch. Laos, Further India. (Cat. No. 217549, U.S.N.M.)

312. Bronze horse.-Height, seven-eighths of an inch. Laos, Further India. (Cat. No. 217550, U.S.N.M.)

313. Bronze bear, on base.-Height, 1 inch. Laos, Further India. (Cat. No. 217546, U.S.N.M.)

314-322. Nine griffins, or dragons, on bases.-Bronze. Called by the Laos "noble animals," which peacefully roam through the splendid gardens of the gods. Height, $\frac{3}{4}$ to $3 \frac{1}{4}$ inches. Laos, Further India. (Cat. Nos. 217537-217545, U.S.N.M.)

323. Demon-queller (Chinese, Chung Kw'ei; Japanese, Shoki.Made or wood; carved and painted. On his head in the upstanding hair is perched a dragon; at his feet is a crouching demon, and over the belt is carved the mask of a monster. The demon queller is in Chinese mythology supposed to be a ghostly protector of the Emperor Ming Hwang (713-762 A. D.). He is usually represented as a truculent giant, clad in official garb and armed with a two-edged sword. $\mathrm{He}$ is sometimes shown as riding upon a lion, but more commonly is engaged in punishing the pigmy demons. The subject forms one of the most frequent inspirations of the Japanese artist, and appears 
in numberless specimens of porcelain, ivory, wood carving, and other works.

This statuette is a specimen of old Japanese carving. Height, 39 inches. Japan. (Plate 90, Cat. No. 130461, U.S.N.M.)

324. Devil dancer's dress.-Consisting of a blue cotton jacket with thin strips of palm leaves stuck into it, giving it the form of fur. Ceylon. (Cat. No. 154980, U.S.N.M.)

325. Devil dancer's dress. - The same as No. 324, only that the jacket is of white cotton. Ceylon. (Cat. No. 154981, U.S.N.M.)

326. Devil dancer's lash.-Ceylon. (Cat. No. 154982, U.S.N.M.)

Sir James Emerson Tennent gives the following explanation and description of the devil dance in Ceylon: "The Singhalese have demon or Sanne for each form of disease, who is supposed to be the direct agent and inflicter, and who is accordingly invoked for its removal. Hence on every domestic occurrence, as well as in every domestic calamity, the services of the katadias or devil priests are to be sought and their ceremonies performed ***. Especially in cases of sickness and danger the assistance of the devil-dancers is implicitly relied on: An altar, decorated with garlands, is erected within sight of the patient, and on this an animal, frequently a cock, is to be sacrificed for his recovery. The dying man is instructed to touch and dedicate to the evil spirit the wild flowers, the rice, and the flesh which have been prepared as the pidaneys, or offerings to be made at sunset, at midnight, and the morning; and in the intervals the dancers perform their incantations, habited in masks and disguises to represent the demon which they personate, as the immediate author of the patient's suffering. In the frenzy of these orgies the katadia, having feigned the access of inspiration from the spirit he invokes, is consulted by the friends of the afflicted, and declares the nature of the disease, and the probability of its favorable or fatal termination. At sunrise, the ceremony closes with an exorcism chanted to disperse the demons who have been attracted by the rite; the devil dancers withdraw with the offerings and sing, as they retire, the concluding song of the ceremony, 'that the sacrifice may be acceptable and the life of the sufferer extended.' " ${ }^{16}$ And describing the performance of such a dance the same author says: "We witnessed the extravagances of two professional devil dancers, who were performing a ceremony in front of a little altar, for the recovery of a patient who was dying close by. It is difficult to imagine anything more demoniac than the aspect, movements, and noises of these wild creatures; their features distorted with exertion and excitement and their hair tangled in ropes, tossed in all directions, as they swing round in mad contortions." 17

\footnotetext{
16 Sir J. E. Tennent, Ceylon. An account of the island, physical, historical, and topographical. London, 1860, vol. 1, p. 540 .

17 Idem, vol. 2, p. 581.
} 
327. Geomantic compass (Chinese, lo-king, or lo-pan).-Consisting of a disk of lacquered wood, beveled down at the bottom to the shape of a saucer. The upper surface carries in its center a small compass, around which run 17 inscribed concentric circles, containing the sundry geomantic factors, as the 8 permutations of the trigram, the 12 signs of the zodiac, the 24 celestial constellations, and so forth. It represents the ancient Chinese system of cosmogony and natural philosophy, and forms the basis of a system of divination.

Geomancy, or, as the Chinese call it, "wind and water," rules (fung-shui), is much used by the Chinese for divining future events, or ascertaining the luckiness or unluckiness of any event, or selecting sites for houses, cities, and especially burial places, which are supposed to have important results on the prosperity of the living. The principles of geomancy depend on two supposed currents running through the earth, known as the dragon and the tiger; a propitious site has these on its left and right. A skillful observer (fung-shui siensang, or "wind and water doctor") can detect and describe such currents with the help of the compass, also the direction of the watercourses, shapes of the male and female ground and their proportions, position of rivers, trees, and mountains, color of the soil, and the changes of the elements. (Compare S. Wells Williams, The Middle Kingdom: New York, 1853, vol. 2, pp. 245-247). Diameter, $7 \frac{1}{2}$ inches. China. (Plate 91, Cat. No. 126954, U.S.N.M.) ${ }^{18}$

328. Divination slips (Chinese, chi en-toong).-Consisting of two bamboo tubes containing slips of bamboo which are inscribed with different characters. The person wishing to know the will of the gods or his fortune shakes the tube and, with averted face, draws out a slip and reads the answer on it. Shanghai, China. (Cat. No. 158304, U.S.N.M.)

329. Divination blocks (Chinese, chiao).-Consisting of two pieces of split bamboo, kidney-shaped, with one side convex and the other flat. The supplicant tosses them into the air in front of the altars of the gods he is supplicating. If both convex sides turn up, the answer is yang-yang, which signifies the male principle of nature, and means "indifferently good"; if both flat sides turn up it is yin-yin, which signifies the female principle of nature, the answer is understood to be negative and unfavorable; if one convex and the other flat, the answer is considered as absolutely affirmative and the prayer as granted. Shanghai, China. (Cat. No. 158301, U.S.N.M.)

330. Divination cards.-Five disks of rough cardboard, painted in red, green, blue, and yellow with concentric circles, with Tibetan letters in the center and surrounded by flames on the margin. Dia-

18 For a detailed explanation of the geomantic compass see j. j. M. de Groot, The Religions of China, Leide, 1897, vol. 3, p. 959, and Paul Carus, Chinese Thought, Chicago, 1907, p. 58. 
meter, $4 \frac{1}{4}$ inches. Tibet. (Cat. No. 311864, U.S.N.M.) Bequest of Miss Elizabeth S. Stevens.

331. Divination cards.-Nine cardboards, painted in the same colors as the preceding No. 330, with various grotesque monstrous animals. Length, $4 \frac{1}{4}$ inches; width, $3 \frac{1}{2}$ inches. Tibet. (Cat. No. 311865, U.S.N.M) Bequest of Miss Elizabeth S. Stevens.

332. Book of divination.--Manuscript in Pali on palm leaves, inclosed in a wooden case. The leaves and the case are perforated through the center for the passing of a cord which holds the book together. Length, $2 \frac{1}{2}$ inches; width, $1 \frac{1}{2}$ inches. Laos, Further India. (Cat. No. 217647, U.S.N.M.)

333. Amulet case (Tibetan, gavo).-Made of copper in shape of shrine, with two handles or ears on either side for suspension. The front of the case is richly adorned in repoussé work with figures of birds, lotus, and other floral designs, and set with eight medallions of gilt brass, representing the eight glorious emblems figured on Buddha's footprint, namely, (1) the conch-shell trumpet of victory; (2) the umbrella; (3) the vase; (4) the victorious banner; (5) the golden fish; (6) the lucky diagram; (7) the lotus; and (8) the wheel. Amulet boxes of wood, silver, copper, or leather, in which are carried charms against various accidents, are worn by the Tibetans around the neck, or suspended from the girdle, while the larger ones are affixed over the head in the house or tent. They contain some meaningless Sanscrit inscription, a few fragments of the cast-off robe of a saintly lama, peacock feathers, supposed to keep off moths, sacred kusa grass, etc. In front of the case is an opening for the image of a deity (missing in this specimen). Height, 8 inches; width, $5 \frac{1}{4}$ inches; depth, $3 \frac{1}{4}$ inches. Probably Tibet. (Plate 92, Cat. No. 311793, U.S.N.M.) Bequest of Miss Elizabeth S. Stevens.

334. Amulet case (gavo).-Made of silver. Decorated with the eight glorious emblems, arabesques, and Chinese dragons, and provided with tubes on the sides for the passing of a cord by which it was suspended around the neck or fastened to the girdle. Height, $4 \frac{1}{2}$ inches; width, 3 inches; depth, $1 \frac{1}{2}$ inches. Lhasa, Tibet. (Cat. No. 130391, U.S.N.M.)

335. Amulet case (gavo).-Made of brass, decorated with plant designs in filigree work, and provided with handles on the sides for suspension. On top are three porcelain beads, representing the triratna (see No. 297), painted blue in imitation of turquoise, the color of Tara (see No. 155), who is usually depicted with a bluish-green complexion. In the opening, under glass, is a terra-cotta miniature figurine of the goddess Marichi (Tibetan, odzez canma), represented seated on a lotus in the witness position, with three faces, of which the left is that of a sow, and eight arms, holding various weapons, as the thunderbolt 
(vajra), a bow and arrow, a club or ax. Originally the gooddess of dawn, she was coupled with the myth of the primeval productive sow. She is also considered as the consort of the demon-general Tamdrin (Hayagriva, see No. 158), and is believed to be incarnated in the abbess of the convent of Palti Lake in Tibet. Height, 3 inches; width, $2 \frac{1}{2}$ inches. Tibet. (Cat. No. 311795, U.S.N.M.) Bequest of Miss Elizabeth S. Stevens.

336. Charm (copy).-Consisting of a diamond-shaped lattice frame, attached to a bamboo pole and having various structures and carvings of fishes fastened to it. It is set up in a corner of the rice field before the planting of the rice. The carvings of the fishes represent Buddha in one of his incarnations as a fish (compare also, for the signification of the fish, No. 197). After this charm has been set up nine stalks of rice are planted. As each rice stalk is planted the formula: Namo tasso bhazarato arahato sammasam-buddhassa is repeated, and an offering of flowers, rice, curry, and chicken meat is placed on a stand beneath the fishes. The whole area is then fenced in and remains sacred until the rice is harvested. Height, 32 inches. Laos, Further India. (Cat. No. 217667, U.S.N.M.)

337. Charm.-Consisting of a bamboo cylinder, lacquered and gilt, strung on a cotton cord. Laos, Further India. (Cat. No. 217644, U.S.N.M.)

338. Charm.-Consisting of stone, copper, and zinc beads, and a crystal of pyrites strung on a cotton cord. Laos, Further India. (Cat. No. 217645, U.S.N.M.)

339. Amulet (peck-che, seng-die).-Consisting of a black stone, polished, with concave sides. "The possessor of this stone is protected against wounds by bullets, knives, swords, and remains well and happy." One-half of an inch square. Laos, Further India. (Cat. No. 217646, U.S.N.M.)

340. Amulet, "lucky crystal."-Protecting against evil influences. Laos, Further India. (Cat. No. 217648, U.S.N.M.)

341. Amulet.-Consisting of a knot of palm leaf, inscribed with auspicious sentences. It is tied around the neck of children to protect them against evil influences. Laos, Further India. (Cat. No 217649, U.S.N.M.)

342. "Naga cloth."-Piece of cotton cloth, painted with circles, squares, and pyramidal figures between the winding coils of serpents (Nagas) or dragons, and inscribed with incantations. It is to "protect against all manner of evil and bodily harm, and, kept in the house, it protects against fire." Length, 48 inches; width, 36 inches. Laos, Further India. (Cat. No. 217650, U.S.N.M.)

343. "Naga cloth."-Piece of cotton, with a large magic square inclosing a serpent or dragon in the center, and four smaller squares 
on one margin, drawn in India ink, and a Pali inscription. Length, 18 inches; width, 27 inches. Laos, Further India. (Cat. No. 217651, U.S.N.M.)

344. "Naga cloth."-Piece of bleached muslin. The edges are inscribed in squares or checkers. The center is filled with four seated figures in witness position and four standing ones, inclosed within a garland. The designs are painted in yellow and vermilion. 18 inches square. Laos, Further India. (Cat. No. 217652, U.S.N.M.)

345. "Naga cloth."-Piece of cotton with inscribed squares and adorned with figures of men, birds, and fishes and floral designs. Length, 17 inches; width, 36 inches. Laos, Further India. (Cat. No. 217653 , U.S.N.M.)

346-349. Native medicine.-Four bags containing from 4 to 24 different substances, as various woods, bones, pieces of Buddha's alms bowl, etc. These are rubbed on a stone, and the resulting powder washed off in water which is given to the patient to drink. Each bag is labeled and selected according to the sickness. Laos, Further India. (Cat. No. 217654, U.S.N.M.)

350. Piece of oval sandstone.-Cut out on the upper surface. Supposed to have been used for grinding or rubbing medicine, but more probably for sharpening some instrument. Length, 3 inches; width. $1 \frac{1}{2}$ inches. Laos, Further India. (Cat. No. 217655, U.S.N.M.)

351. Kakemono.--Representing Buddha in the center surrounded by saints or Bodhisattvas. Painted in gold and various colors, The style much resembles that of the illuminated missals of the Middle Ages. A Kakemono is a scroll of paper or cloth, with a picture or inscription painted or printed upon one side. The designs are usually religious. They are rolled upon a cylindrical stick, and are intended to be hung upon the wall. Japan. (Cat. No. 305813, U.S.N.M.) Gift of Mrs H. B. Buckingham and Isabel C. Freeman.

352. Kakemono.--Representing Buddha with 12 saints or arhats. The faces are painted white, the caps red, the robes yellow, the halos light green. China (?). (Cat. No. 154273, U.S.N.M.)

353. Kakemono.-Monochrome. Representing Daruma by Toteku the Unkoku School (1538-1610 A. D.). Daruma was the twentyeighth Buddhist patriarch. He arrived in China in $520 \mathrm{~A}$. D. and converted the then emperor. It is said he came to Japan in 613 A. D. and died there. During nine years he sat in profound meditation, neither moving or speaking, and when he returned to consciousness of his surroundings his legs had become paralyzed owing to their long disuse. $\mathrm{He}$ is often depicted in a humorous manner, with a comical head and round body, without arms and legs, which are supposed to have withered away from disuse. Japan. (Cat. No. 154273, U.S.N.M.) 
354. Kakemono.-Buddhist ecclesiastic, seated in a chair holding in his right hand a vajra (?); in the left, a rosary. Head and neck are painted white; the robe is in vermilion. Above are trees. China (?). (Cat. No. 154273, U.S.N.M.)

355. Kakemono.-Monochrome. Daikoku, one of the Japanese seven gods of fortune (see No. 167), with mallet, seated on rice bags. Japan. (Cat. No. 154273, U.S.N.M.)

356. Kakemono.-Monochrome. Ebisu, with fishing rod and fish (see No. 167). Japan. (Cat. No. 154273, U.S.N.M.) 


\section{$2 \mathrm{BHL}$ Biodiversity Heritage Library}

Casanowicz, Immanuel Moses. 1921. "Descriptive catalogue of the collection of Buddhist art in the United States National Museum." Proceedings of the United States National Museum 59(2371), 291-347.

https://doi.org/10.5479/si.00963801.59-2371.291.

View This Item Online: https://www.biodiversitylibrary.org/item/32485

DOI: https://doi.org/10.5479/si.00963801.59-2371.291

Permalink: https://www.biodiversitylibrary.org/partpdf/18479

\section{Holding Institution}

Smithsonian Libraries

\section{Sponsored by}

Smithsonian

\section{Copyright \& Reuse}

Copyright Status: NOT_IN_COPYRIGHT

This document was created from content at the Biodiversity Heritage Library, the world's largest open access digital library for biodiversity literature and archives. Visit BHL at https://www.biodiversitylibrary.org. 